\title{
A Review of Salvage Treatment Options for Disease Progression After Radiation Therapy for Localized Prostate Cancer
}

Ethan M Steele, BS ${ }^{1}$; Jordan A. Holmes, MD, MPH ${ }^{1,2}$

\section{Author affiliations:}

1 Department of Radiation Oncology, Indiana University School of Medicine, Indianapolis, IN;

2 IU Simon Cancer Center, Indianapolis, IN

\section{Corresponding Author:}

Dr. Jordan A Holmes

Department of Radiation Oncology

IU Simon Cancer Center

535 Barnhill Drive, Room RT 041

Indianapolis, IN 46202

Tel: 317-944-0553

E-mail: jordan.a.holmes@gmail.com

Keywords: Prostate Cancer, Radiation Recurrence, Salvage Treatment Modalities, Surgery, Radiation Therapy

Conflicts of Interest: None

This is the author's manuscript of the article published in final edited form as:

Steele, E. M., \& Holmes, J. A. (2019). A review of salvage treatment options for disease progression after radiation therapy for localized prostate cancer. Urologic Oncology: Seminars and Original Investigations, 37(9), 582-598. https://doi.org/10.1016/j.urolonc.2019.04.030 


\section{Abstract:}

Recurrence of prostate cancer after initial treatment with radiation therapy is highly dependent on pretreatment risk group and unfortunately, a proportion of patients fail primary treatment. The treatment of recurrence after primary radiation is rapidly changing with advances in imaging and it is important to distinguish those with a local failure from those with distant failure. If disease remains locally confined, salvage treatment with a variety of techniques can still provide a potential cure. Patients with distant failure are often treated with androgen deprivation, or in those with a shorter life expectancy, conservative management. In patients with a higher burden of metastatic disease, there is emerging evidence that chemotherapy and advanced androgen therapy can improve survival. We review the relevant literature on available salvage treatment options and appropriate patient selection for patients with recurrent prostate cancer after radiation therapy. We report on the efficacy and adverse effects of the currently available local salvage modalities including salvage radical prostatectomy, high dose rate and low dose rate brachytherapy, cryotherapy, high intensity focused ultrasound, and stereotactic body radiation therapy. We additionally discuss diagnosis of oligometastatic disease on imaging and current approaches to treatment with either radiation or surgery. While a full review of chemotherapy and advanced androgen therapies is beyond the scope of this article we briefly discuss their use in the treatment of newly diagnosed recurrence after radiation. 


\section{Introduction}

Prostate cancer is the most commonly diagnosed non-dermatologic cancer in men in developed countries and has the second highest incidence to lung cancer among males globally. ${ }^{1}$ Definitive treatment of disease confined to the prostate most commonly involves surgery, radiation therapy (RT) or a combination of both and patients over the age of 65 are more likely to receive radiation therapy than surgery. ${ }^{2,3}$

Failure of primary treatment is separated into biochemical failure and clinical failure. Biochemical failure relates to rising serum PSA after treatment, and is used to predict future clinical failure. Clinical failure is when a patient presents with symptoms related to local progression or distant metastasis of prostate cancer after treatment. Failure after primary radiation therapy is heavily influenced by pre-treatment risk grouping, but Nguyen et al. report that between $20 \%$ and $50 \%$ of patients may experience biochemical failure. ${ }^{4}$ Rising PSA often predates clinical metastatic disease by many years and a subset of those with biochemical failure may continue to have organ-confined disease and benefit from additional local treatment. ${ }^{5}$ Most patients with biochemical failure are managed with observation or androgen deprivation therapy (ADT) with only a small minority receiving local salvage therapy, though local salvage therapy may be underutilized. ${ }^{6}$

In this review we will discuss which patients may benefit from local salvage therapy after failure of primary radiation therapy, and the general management of biochemical failure after primary radiation therapy. We will explore the various salvage treatment modalities and compare survival and morbidity outcomes.

\section{Patient selection}

Failure after primary treatment is most often diagnosed as biochemical recurrence (BCR) due to rising serum PSA. BCR after radiation therapy is defined as a rise of $\geq 2 \mathrm{ng} / \mathrm{mL}$ above post-treatment nadir PSA 
value (Phoenix Definition) $)^{7}$. While recurrence is defined based on change in PSA, the absolute PSA value is associated with likelihood of recurrence and is predictive of time to metastatic disease ${ }^{8,9}$. Additionally, the absolute PSA at the time of salvage therapy is associated with biochemical failure free survival ${ }^{10}$.

Among patients with biochemical recurrence in whom the site of recurrence is detected, disease isolated locally in the prostate gland and seminal vesicle is most common. According to a study of patients with clinically detectable recurrence at Memorial Sloan Kettering Cancer Center, the anatomic distribution of recurrence was $41.6 \%$ local, $9.7 \%$ lymphotropic, $20.3 \%$ osteotropic, and $28.5 \%$ multiorgan/visceral ${ }^{11}$.

Patients with metastatic disease, or distant failure, are not often candidates for curative intent local salvage therapy, and it is therefore of particular importance to attempt to identify these patients to spare them the morbidity of a salvage treatment from which they may not benefit. The standard metastatic workup after biochemical failure has been a bone scan and cross-sectional imaging of pelvis for decades. However, advances in technology including positron-emission tomography (PET) with ${ }^{18} \mathrm{~F}$-fluciclovine, choline $\mathrm{C}-11$, or ${ }^{18} \mathrm{~F}$ sodium fluoride along with whole body MRI or CT have allowed for earlier detection of metastatic disease, and detection of small volume loco/regional disease recurrence. ${ }^{12,13}$ Imaging using radio-labelled prostate specific membrane antigen (PSMA) is an additional promising new technology to help identify disease ${ }^{14,15}$. Despite these more sensitive tests, many patients who undergo local salvage treatment will develop distant failure, some of whom presumably had undetectable micrometastasis at the time of salvage and would have benefited from more restrictive patient selection. Patients with higher T stage and Gleason score at diagnosis as well as PSA doubling time (PSA-DT) after recurrence of less than 6 months are more likely to develop distant metastasis after attempted local salvage and may not benefit from local treatment. ${ }^{16}$

The recent advances in imaging have also allowed for identification of "oligometastasis" which describes the state of having limited metastatic spread, often to a single lymph node or distant locus. Patients with oligometastases may still be considered candidates for curative treatment and benefit from focal therapy to the identified lesion(s). 
Patients with overt metastatic disease will not benefit from local salvage therapy, but in patients without evidence of metastasis the benefit of local salvage compared to ADT or observation is a controversial topic. Conclusions are based largely on small retrospective studies. The NCCN suggests that candidates for local salvage therapy are patients with original clinical stage T1-T2, Nx or N0, with life expectancy greater than 10 years, pre-salvage serum PSA $<10 \mathrm{ng} / \mathrm{mL}$, no evidence of distant metastasis based on imaging and PSA-DT, and a positive prostate biopsy. ${ }^{17}$ None of the studies discussed in this article included only those patients meeting all of these criteria and it is therefore important to note the differing inclusion criteria for each study (Table 1).

\section{Local salvage modalities}

In patients who have radiographic and/or biopsy proven disease confined to the prostate after initial treatment with radiation therapy, local salvage treatment provides the possibility of a cure. However, only a small proportion of patients who fail primary radiation therapy receive local salvage treatment and there is currently no consensus on a best salvage treatment modality. ${ }^{6}$ In evaluating local salvage options it is important to note that there are different definitions of biochemical failure, significant disparity in patient characteristics, and variation in the use of prior, neoadjuvant, and adjuvant ADT across the literature on this subject (Table 1).

\subsection{Radical Prostatectomy}

Salvage radical prostatectomy (SRP) after external beam radiation therapy (EBRT) is more technically difficult and is associated with higher potential for morbidity than primary radical prostatectomy (RP) due to effects of primary radiation on normal tissues in the pelvis. For these reasons SRP should be performed by an experienced physician at a high volume center and patients should also be counselled regarding the increased risk of side effects with this procedure. Removal of the prostate gland is achieved by open approach or minimally invasive robotic or laparoscopic technique. Nerve sparing techniques attempt to 
preserve erectile function by leaving the neurovascular bundles intact but are only appropriate when tumor control will not be compromised. Pelvic lymph node dissection is often performed at the discretion of the surgeon and may be especially appropriate in the setting of oligometastatic disease confined to pelvic lymph nodes.

\section{Oncologic Outcomes}

In a multi-institutional, international case series, Chade et al. reported on the treatment of 404 patient with SRP after initial RT. The median age was 65 years and median pre-salvage PSA was $4.5 \mathrm{ng} / \mathrm{mL}$. At a median follow up of 4.4 years they reported 5 year biochemical failure free survival (bFFS) of $48 \%$, metastasis free survival (MFS) of $83 \%$ and cancer specific survival (CSS) of $92 \% .{ }^{18}$ These figures are similar to those reported by two smaller single center studies. Mandel et al. reported 5 year bFFS of $48.7 \%$ and CSS of $88.7 \%$ while Sanderson et al. reported progression free survival (PFS), which they define as time to ADT initiation or progression, of $47 \%$ at 5 years. ${ }^{19,20}$ In a case series of 199 patients treated at the Naval Medical Center, bFFS was $58 \%$ and $48 \%$ at 5 and 10 years respectively. ${ }^{21}$ Despite their slightly higher bFFS, they found a slightly lower CSS of $79 \%$ and $65 \%$ at 5 and 10 years respectively.

Taken as a whole, the literature for SRP suggest that in carefully selected patients with residual disease in the prostate, approximately half can be cured with surgery. However, it is important to note that patient selection for salvage is crucial, and most of the published series of SRP span many decades in which time radiation, surgical and imaging techniques have changed significantly.

\section{Adverse Effects}

As previously mentioned the morbidity of SRP can be significant. Ward et al. reported on morbidity after SRP, noting that $4 \%$ of SRP patients suffered operative rectal injury which increased to $10 \%$ of the patients who had undergone cystoprostatectomy due to radiation induced adhesions involving the rectal wall, bladder base, or trigone. ${ }^{21}$ In a series of patient surveys from 33 patients at a median of 7.5 years 
from SRP, Sanderson et al. reported that $73 \%$ of respondents found their overall urinary function to be “small," "very small," or "no" problem, while continence rates were higher among those who had received an artificial urethral sphincter. ${ }^{20}$ Not surprisingly, they found a clinically significant improvement in sexual function in patients with inflatable penile prosthetic implant over patients with nerve sparing SRP, but found no difference in sexual bother between the groups. Bladder neck contractures were a common complication in both studies, occurring in $22 \%-41 \%$ of patients. ${ }^{20,21}$

\subsection{Brachytherapy}

In patients who have previously received EBRT, brachytherapy (BT) can be an appealing option due to the ability to deliver a very conformal high dose to the target lesion while minimizing dose to surrounding healthy tissue. There is also the convenience of as few as a single treatment session. The published literature for salvage brachytherapy includes a patient population that was largely treated with ADT prior to salvage brachytherapy, and variable rates of neoadjuvant ADT between study populations results in a wide range of biochemical control outcomes. However, in more contemporary and less pre-treated populations, low dose rate or high dose rate brachytherapy appear to be able to cure about half of all local failures in patients who are candidates for the procedures.

\subsubsection{Low Dose Rate Brachytherapy}

Low dose rate brachytherapy (LDR BT) is performed by implanting radioactive seeds directly into and around the target lesion or the entire prostate gland. Seeds remain in the gland permanently and deliver dose slowly over many months as the isotopes decay. Frequently used radioisotopes include ${ }^{125}$ I (half-life 59.4 days) and ${ }^{103} \mathrm{Pd}$ (half-life 17.0 days).

\section{Oncologic Outcomes}

The largest reported case series of patients receiving salvage BT was published by Vargas et al. In this study of 69 patients, $89 \%$ of the patients received ADT neoadjuvantly and or adjuvantly and if patients 
demonstrated serum PSA $>5 \mathrm{ng} / \mathrm{mL}$ while on ADT their cancer was considered castration resistant. Their 5-year bFFS was $73 \%$ for castration sensitive and $20 \%$ for castration resistant cancers. MFS and overall survival (OS) were $90 \%$ and $64 \%$ at 5 years. ${ }^{22}$ In a study of largely high risk patients, Baumann et al. report on reduced dose brachytherapy with concurrent ADT and found relapse free survival to be $79 \%$ and $67 \%$ at 5 and 7 years respectively and distance metastasis free survival was $93 \%$ and $86 \%$ at 5 and 7 years ${ }^{23}$. Grado et al. reported on a series of 49 patients with median age 73.3 and pre-salvage PSA 5.6 excluding patients with neoadjuvant ADT or prior orchiectomy. With median follow up of 5.3 years they report 5-year bFFS, CSS, and OS of 34\%, 79\%, and 56\% respectively. ${ }^{24}$ Of these 49 patients, 11 had already failed one additional salvage modality and 2 had failed two previous modalities. More recently, Burri et al. reported on 37 patients at Mount Sinai with median age of 70 years and pre-salvage PSA of $5.6 \mathrm{ng} / \mathrm{mL}$. They reported a bFFS of $54 \%$, CSS of $96 \%$ and OS of $74 \%$ at 10 years. ${ }^{25}$

\section{Adverse Effects}

In a phase II prospective study of 92 patients previously treated with EBRT, Crook et al. found that LDR BT was well tolerated, with only $14 \%$ of patients experiencing late grade 3 GI or GU adverse events and no reported early or late grade 4 or higher events ${ }^{26}$. Moman et al. reported the toxicity experienced by 31 patients at 9 years median follow up and they found that $87 \%$ of their patients experienced grade $1-2$ GU toxicity in the early phase within 90 days of treatment which decreased to $55 \%$ after 90 days. ${ }^{27}$ The prevalence of grade $3 \mathrm{GU}$ toxicity increased from $3 \%$ to $19 \%$ from the early to the late phase. Grade $1-2$ GI toxicity occurred in $55 \%$ and $51 \%$ of patients in the early and late phase respectively. Grade 3 GI toxicity was rare and occurred in only $6 \%$ of patients in the late phase and no patients experienced grade $\geq 4$ GI or GU toxicity. Grado et al. reported toxicities among their 49 patients which included two cases of persistent gross hematuria, three patients with significant penile dysuria, and two patients with rectal ulcers. ${ }^{24}$ They found that acute urinary symptoms were common but typically transitory.

\subsubsection{High Dose Rate Brachytherapy}


Administration of high dose rate brachytherapy (HDR BT) involves insertion of catheters into the prostate guided by a perineal template. Highly radioactive isotopes such as ${ }^{192} \mathrm{Ir}$ are inserted and moved through the catheters to distribute dose per the treatment plan. In some cases, patients may have the catheters implanted more than once and often multiple doses are delivered hours apart with a single implant.

\section{Oncologic Outcomes}

Chen et al. published a retrospective series of 52 patients undergoing salvage HDR BT with 36 Gy in 6 fractions across 2 separate implants. Patients had a median age of 67.5 and median pre-salvage PSA of $5.0 \mathrm{ng} / \mathrm{mL}$. With median follow up of 59.6 months they found 5 -year bFFS of $51 \%$ with OS of $92 \%{ }^{28}$ In a prospective phase II study of HDR BT in 42 patients treated with 32 Gy in 4 fractions using a single implant, Yamada et al. reported a 5 year bFFS of $68.5 \%$ and OS of $79 \%{ }^{29}$ This study excluded patients with pre-salvage PSA $>10 \mathrm{ng} / \mathrm{mL}$ and any patient with international prostate symptom score greater than 15.

\section{Adverse Effects}

Yamada et al. additionally evaluated treatment toxicity in their 42 patients. ${ }^{29}$ They found acute grade 1-2 GU toxicity in $78 \%$ of patients, and up to $96 \%$ of patients in the late phase. There were 3 total grade $3 \mathrm{GU}$ toxicity events with no grade 4 or greater. GI toxicity was largely transient rectal bleeding without any grade 3 or greater events. Chen et al. reported grade $\geq 2$ acute and late GI toxicity in $38 \%$ and $56 \%$ of patients respectively with only $4 \%$ of patients experiencing any grade 2 GI toxicity. ${ }^{28}$ Acute sexual dysfunction was found to be grade $\geq 2$ in $19 \%$ of patients, increasing to $35 \%$ of patients for late dysfunction.

\subsection{Cryotherapy}

Cryotherapy, also known as cryosurgery and cryoablation therapy, involves placement of probes within the prostate that undergo extreme cooling using argon gas. Prostate tissue is consumed by an expanding 
ball of ice that is monitored by transrectal ultrasound often through multiple freeze-thaw cycles. ${ }^{30}$ Rapid freezing of the tissue results in ice crystal formation that leads to cell death. ${ }^{31}$ A urethral warming catheter is used to prevent urethral tissue damage.

\section{Oncologic Outcomes}

Wenske et al. published a series of 328 patients who received salvage cryotherapy between 1994 and 2011 at Columbia University and had mostly received EBRT as primary treatment (49 patients had primary LDR BT and 20 patients had primary cryotherapy). ${ }^{32}$ The median age was 65.8 years and median pre-salvage PSA was $4.0 \mathrm{ng} / \mathrm{mL}$ in the study. Their bFFS was $63 \%$ and $35 \%$ at 5 and 10 years respectively. CSS was $91 \%$ and $79 \%$ and OS was $74 \%$ and $45 \%$ at 5 and 10 years respectively. Lu et al. reported their series of 187 patients with mean follow up of 7.5 years and found disease free survival (DFS), which included results of serum PSA and some patients who received biopsies, to be $47 \%$ at 5 years and $39 \%$ at 10 years while MFS and OS were $87 \%$ and $95 \%$ respectively at 5 years. ${ }^{33}$

\section{Adverse Effects}

Long term complications of salvage cryotherapy were assessed with a survey of 112 patients at a median age of 68.8 years and mean follow up of 16.7 months..$^{30,34}$ They found that $72 \%$ of patients reported incontinence, $66 \%$ reported medium to severe voiding symptoms, $63 \%$ lost potency among those who were potent prior to cryotherapy, and $44 \%$ reported chronic perineal pain. ${ }^{34}$ They additionally found a $33 \%$ overall satisfaction rate with cryotherapy. A similar report by $\mathrm{Ng}$ et al. fund that among 187 patients treated with salvage cryotherapy $8 \%$ required surgery to address complications after treatment. ${ }^{35}$

\subsection{High Intensity Focused Ultrasound}

High-intensity focused ultrasound (HIFU) is used in the treatment of localized prostate cancer through the ablation of tissue by heat generated by a beam of focused ultrasound using a transrectal probe. ${ }^{36}$ The US Food and Drug Administration (FDA) approved HIFU to be marketed for use in prostate tissue ablation 
only as recently as 2015 due to lack of substantial clinical outcome data. ${ }^{37}$ There is limited data on HIFU outcomes relevant to patient decision making for primary treatment of prostate cancer and with this lack of primary treatment data, it follows that evidence in the context of local salvage therapy is even more sparse.

\section{Oncologic Outcomes}

Crouzet et al. published the largest series of 418 patients undergoing S-HIFU from 1995-2009 in an international, multi-institutional analysis. ${ }^{38}$ Mean patient age was 68.6 years, on average 5.1 years after primary treatment. Mean pre-salvage PSA was $6.8 \mathrm{ng} / \mathrm{mL}$ and median follow up was 3.3 years. Some patients had a history of ADT use but none continued ADT after HIFU. Most patients received one HIFU session, with about $13 \%$ of patients receiving two or three sessions. They reported $37 \%$ of patients were free from initiation of ADT at 5 years but also report a bFFS of $49 \%$ overall at 5 years. Gelet et al. reported 30 month actuarial disease free rate (bFFS or negative biopsy) as $38 \%$ in their series of 71 patients with a median pre-salvage PSA of $5.7 \mathrm{ng} / \mathrm{mL}$, and $13 \%$ of patients developed metastases. ${ }^{39}$ Kanthabalan et al. reported a bFFS of $48 \%$ at 3 years with $92 \%$ overall survival among 150 patients. ${ }^{40}$ Interestingly Uddin et al. biopsied a portion of their cohort of 84 patients treated with S-HIFU and found that $43 \%$ of those biopsied ( $25 \%$ of the entire cohort) demonstrated a positive biopsy after S-HIFU treatment. ${ }^{41}$

\section{Adverse Effects}

HIFU is less invasive than prostatectomy, but can still lead to significant morbidity. In an earlier study Crouzet et al. reported $16 \%$ of patients experienced bladder outlet obstruction. They also reported that $2 \%$ and 3\% of patients developed a urethrorectal fistula and pubic bone osteitis respectively. ${ }^{42}$ Gelet et al. found that $6 \%$ of their patients developed urethrorectal fistula. ${ }^{39}$

\subsection{Stereotactic Body Radiation Therapy}


Stereotactic body radiation therapy (SBRT) is similar to EBRT except that the treatment dose is typically delivered in 2-5 total fractions. SBRT is an appealing non-invasive way to approximate the dosimetry achieved by HDR BT ${ }^{43}$ SBRT is a relatively new technique and there are few studies investigating the use of SBRT for local salvage therapy in prostate cancer.

Presenting preliminary results of their prospective study of 29 patients treated with salvage SBRT with 34 Gy in 5 fractions, Fuller et al. reported a bFFS of $82 \%$ at 2 years. The median age was 73 and median presalvage PSA was $3.1 \mathrm{ng} / \mathrm{mL}$. They found GU toxicity of grade $\geq 2$ in $18 \%$ of patients and no patients with GI toxicity above Grade 1 . Of 10 patients who were sexually potent prior to SBRT, 4 reported no significant change while 3 experienced a major decrease in potency ${ }^{44}$.

In another small series, Leroy et al. reported bFFS of 54\% at two years among their 23 patients. Patients received 36 Gy in 6 fractions and had a median pre-salvage PSA of $2.5 \mathrm{ng} / \mathrm{mL}$. They reported $26 \%$ of patients with GU toxicity grade $\geq 2$ and two patients with grade 2 rectal toxicity. ${ }^{45}$

\section{Treatment of Oligometastatic Disease}

Treatment of oligometastatic disease typically consists of either radiation or surgery. Radiation therapy usually consists of SBRT while surgery involves salvage pelvic lymph node dissection (sPLND) when disease is confined to the pelvic nodes and metastasectomy for other isolated lesions. While there is growing interest and ongoing research investigating treatment of oligometastatic prostate cancer, published data remains sparse.

Ost et al. published a phase II trial comparing surveillance to metastasis-directed therapy (MDT) with either SBRT or surgery. ${ }^{46}$ They found that the MDT group had a significantly longer median time to initiating ADT and no patients in the MDT group experienced grade 2 or greater toxicity. An Italian study of 40 patients evaluated the use of SBRT in patients with isolated lymph node recurrent prostate cancer. ${ }^{47}$ They reported a two year bFFS of $44 \%$. 
Surgery for oligometastatic disease can target distant metastases, but most commonly will target lymphatic disease with salvage pelvic lymph node dissection (sLND). A German study of sLND investigated outcomes of surgery in patients with recurrent prostate cancer with lymphatic disease detected on imaging. ${ }^{48}$ Most patients had received prostatectomy as primary treatment, but $10 \%$ of patients had received RT. Of the 69 patients included in the analysis, 27.3\% demonstrated bFFS at 5 years and $35.1 \%$ remained free from systemic therapy at 5 years. Postoperative lymphocele occurred in $11.5 \%$ of patients, half of whom required surgical intervention. A study of 52 patients with recurrence after RP at Mayo Clinic found that sLND resulted in bFFS of $45.5 \%$, MFS of $46.9 \%$, and CSS of $92.5 \%$ all at 3 years. ${ }^{49}$ This patient population was free from additional treatment in $46.2 \%$ of cases at last follow up. As with these studies, most evidence for sLND is in patients who underwent RP for primary treatment. Patients with recurrence after primary RT differ from RP patients in that they may have received previous radiation to their lymph nodes, and they retain their prostate gland. However, if imaging identifies disease isolated to the lymph nodes and surgical resection is feasible, it may be reasonable to assume similar outcomes in patients with recurrence after RT.

\section{Systemic management options}

In recent studies PET/CT is able to identify a lesion(s) in over $70 \%$ of patients with a PSA greater than 0.5. ${ }^{14,15}$ However, advanced imaging is not always available, and even with advanced imaging some patients have only biochemical evidence of disease and are presumed to be metastatic. Patients with diffuse metastatic disease on imaging or other complicating factors may not be candidates for metastasis directed therapy, and for these reasons systemic treatment remains a common option for patients who fail radiation therapy.

\subsection{Androgen Deprivation Therapy}


Androgen deprivation therapy (ADT) is a staple in the treatment of metastatic prostate cancer and has additionally been associated with improved outcomes in localized disease. ${ }^{50,51}$ Patients treated with ADT experience side effects including impotence, decreased libido, hot flashes, fatigue, and weight gain among others. There is evidence of an association with incident diabetes, coronary artery disease, myocardial infarction, and sudden cardiac death with ADT. ${ }^{52}$

The Timing of Androgen Deprivation (TOAD) trial was a randomized, non-blinded, phase III trial that included patients with biochemical recurrent disease without evidence of metastases (group 1) or who were not eligible for curative treatment (group 2) and evaluated the effect of immediate versus delayed initiation of ADT. Men assigned to the delayed arm were recommended to start ADT at least 2 years after randomization unless they developed symptoms, metastases, or a PSA doubling times of $<6$ months. This study found an improvement in OS in favor of immediate ADT, but among the group 1 patients this benefit did not reach statistical significance ${ }^{53}$ The immediate ADT group had more low-grade side effects, but overall quality of life was similar between the groups. Given the lack of an overall survival benefit for immediate initiation of ADT in patients with biochemical failure, many clinicians will delay initiation of ADT until an arbitrary cut off (e.g. PSA of 10) or until the PSA doubling time is $<6$ months.

\subsubsection{Continuous vs Intermittent Androgen Deprivation Therapy}

Traditionally, ADT was administered continuously beginning at the time of biochemical recurrence, but due to the significant side effects of ADT there has been interest in intermittent androgen deprivation (IAD). IAD allows for a treatment-free period, and in theory fewer side effects. In a randomized controlled non-inferiority trial of 1386 patients, Crook et al. compared IAD to continuous androgen deprivation. IAD was given in 8 month treatment cycles followed by non-treatment until PSA was $>10$.

They found that OS was not inferior in the IAD group versus the CAD group. ${ }^{54}$ The median survival was 8.8 vs 9.1 years in the IAD and CAD groups respectively. Their study additionally found symptom-based quality of life outcomes to favor IAD including hot flashes, desire for sexual activity, and urinary symptoms. In a randomized controlled trial of 1,535 patients with metastatic disease, Hussain et al. 
similarly found fewer adverse events among the IAD group, however they were unable to conclusively demonstrate non-inferiority in regard to survival ${ }^{55}$. This study helps to support the paradigm of intermittent androgen deprivation, however it is difficult to directly apply the outcomes to our patient population since all of their patients had metastatic disease and a minority had been previously treated with radiation.

\subsection{Chemotherapy}

Recent studies have evaluated the efficacy of chemotherapy in patients with locally advanced and/or metastatic prostate cancer. The use of systemic therapy in the context of PSA-only recurrence without evidence of metastasis has been investigated, but these patients have made up a small portion of larger randomized trials.

The STAMPEDE (Systemic Therapy in Advancing or Metastatic Prostate cancer: Evaluation of Drug Efficacy) trial is evaluating various systemic therapies in local recurrent, locally advanced, and metastatic prostate cancer. The patient population being recruited into the STAMPEDE trial ranges from locally advanced (two high risk features) to metastatic, with the majority of patients having newly diagnosed metastatic disease without previous treatment.

In a publication evaluating the benefit of adding docetaxel, zoledronic acid, or both to standard of care (ADT +/- radiation) the STAMPEDE authors randomized 2,962 patients between $2005-2013 .{ }^{56}$ Standard of care demonstrated a median overall survival of 71 months while addition of docetaxel resulted in a median overall survival of 81 months (HR 0.78; 95\% CI 0.66-0.93; $\mathrm{p}=0.006$ ). Addition of zoledronic acid to standard of care and to standard of care plus docetaxel did not demonstrate an advantage compared to standard of care plus docetaxel. Failure free survival favored the docetaxel group over standard of care alone (HR 0.61; 95\% CI 0.53-0.70; $<<0.001$ ). However, the survival benefit in the setting of biochemical failure only is difficult to ascertain as only $6 \%$ of the patients in this study failed primary treatment. In 
addition the survival benefit of chemotherapy came at the added cost of treatment toxicity with a $20 \%$ increase in grade $3-5$ toxicity ( $32 \%$ vs $52 \%)$.

In a separate cohort of 1917 patients, the STAMPEDE authors investigated the effect of ADT alone versus ADT plus abiraterone and prednisolone. Failure free survival was $75 \%$ in the combination therapy group versus $45 \%$ in the ADT alone group (HR 0.29; 95\% CI 0.25-0.34; $<<0.001$ ). Patients who received combination therapy experienced fewer symptomatic skeletal events than those who received ADT alone (HR 0.46; 95\% CI 0.37-0.58; $\mathrm{p}<0.001$ ), but again patients in the combination group were more likely to experience grade 3 or higher toxicity (47\% vs 33\%). ${ }^{57}$ Again in this cohort only $5 \%$ of patients had been previously treated.

For patients with clinical or radiographic evidence of metastatic disease the CHAARTED trial randomized 790 patients with metastatic, hormone sensitive prostate cancer to receive ADT alone or ADT plus docetaxel. ${ }^{58}$ There was an overall survival benefit with the addition of docetaxel over ADT alone (HR 0.61; 95\% CI 0.47-0.80; $\mathrm{p}<0.001$ ). Median time to castration resistant disease was 20.2 months for combined therapy compared to 11.7 months with ADT alone (HR 0.61; 95\% CI 0.51-0.72; $<<0.001$ ). However, again the proportion of patients who had failed previous primary treatment was small $(72.8 \%$ no prior treatment, $19.5 \%$ prostatectomy, and $7.6 \%$ radiation) making extrapolation to failure after primary RT difficult.

In a small phase II study of 41 patients, McKay et al. treated patients with docetaxel, bevacizumab, and ADT after biochemical recurrence following local therapy. ${ }^{59}$ At 1 year after completion of therapy, only $44 \%$ remained free from biochemical recurrence and over half of their patients reinitiated ADT within two years due to disease progression. Additionally $39 \%$ and $12 \%$ of patients experienced grade 3 and grade 4 treatment-related adverse events and $22 \%$ of patients discontinued treatment due to toxicity.

Chemotherapy and advanced hormonal therapy are moving to the forefront of treatment for metastatic prostate cancer, but their role in treating patients after failure of primary radiation remains controversial. 
Taken as a whole, the published randomized trials suggest that patients with a higher burden of disease (clinical or radiographic metastasis) are most likely to benefit from chemotherapy or advanced hormonal therapy after failure of primary radiation.

\subsection{Watchful Waiting}

In patients with recurrence who are elderly, have comorbid conditions, or otherwise elect to forego treatment, watchful waiting may be an appropriate strategy. In a retrospective study of men with PSA failure after radical prostatectomy the median time to development of clinical metastatic disease was 8 years from first biochemical failure, and the median time to prostate cancer specific death was 5 years from development of metastatic disease.$^{60}$ Clearly biochemical failure does not typically indicate imminent death from disease, and therefore in patients with a life expectancy $<10$ years aggressive salvage or hormonal treatment is unlikely to prevent clinical disease manifestation or death.

\section{Conclusions}

Salvage for failure after definitive RT for prostate cancer is a rapidly evolving field as newer imaging technologies are detecting more localized/oligometastatic disease. While there is no high quality comparative data to guide the decision of which local salvage therapy is best, it is reasonable to offer local salvage based on institutional strengths in patients with a pre-salvage PSA $<10$, life expectancy $>10$ years, PSA doubling time of $>6$ months, no evidence of distant disease, and either biopsy proven or imaging evidence of local failure. For patients with biochemical failure and no measurable disease, ADT

remains the backbone of treatment, and this can be given continuously or intermittently with no difference in OS. Chemotherapy and advanced hormonal therapy have shown a survival benefit in patients with metastatic disease, but the benefit is likely greatest in those with a higher burden of disease. 
Aknowledgements: This publication was made possible with partial support from Grant \#UL1TR002529

(A. Shekhar, PI) from the National Institutes of Health, National Center for Advancing Translational Sciences, Clinical and Translational Sciences Award. 
Table 1: Summary of studies evaluating salvage treatment options for prostate cancer

\begin{tabular}{|c|c|c|c|c|c|}
\hline Study & Study type & $\begin{array}{l}\text { Patient } \\
\text { Characteristics }\end{array}$ & Treatment & Oncologic Outcomes & Toxicity Outcomes \\
\hline \multicolumn{6}{|c|}{ Salvage Radical Prostatectomy (SRP) } \\
\hline $\begin{array}{l}\text { Chade et al. }^{18} \\
2011 \\
\mathrm{~N}=404\end{array}$ & $\begin{array}{l}\text { Retrospective, } \\
\text { international case } \\
\text { series } \\
1985-2009\end{array}$ & $\begin{array}{l}\text { Median age } 65 \\
\text { Median pre-salvage PSA } 4.5 \mathrm{ng} / \mathrm{mL} \\
\text { Median FU } 4.4 \text { yrs }\end{array}$ & SRP & $\begin{array}{l}\text { bFFS: } 48 \% \text { at } 5 \text { yrs, } 37 \% \text { at } 10 \mathrm{yrs} \\
\text { MFS: } 83 \% \text { at } 5 \text { yrs, } 77 \% \text { at } 10 \mathrm{yrs} \\
\text { CSS: } 92 \% \text { at } 5 \text { yrs, } 83 \% \text { at } 10 \mathrm{yrs} \\
\text { Pre-SRP PSA and gleason score at SRP predicted BCR } \\
\text { and metastasis and positive LNs predicted metastasis }\end{array}$ & \\
\hline $\begin{array}{l}\text { Mandel et a. }{ }^{19} \\
2016 \\
\mathrm{~N}=55\end{array}$ & $\begin{array}{l}\text { Single center, } \\
\text { German case series } \\
2007-2012\end{array}$ & $\begin{array}{l}\text { Radiation OR HIFU recurrent disease } \\
58.2 \% \text { of patients met } \\
\text { Mean pre-salvage PSA } 9.5 \mathrm{ng} / \mathrm{mL} \\
\text { Median FU } 3.0 \text { yrs }\end{array}$ & SRP & $\begin{array}{l}\text { bFFS: } 48.7 \% \text { at } 5 \text { yrs } \\
\text { MFS: } 69 \% \text { at } 5 \text { yrs } \\
\text { CSS: } 88.7 \% \text { at } 5 \text { years } \\
\text { Primary LDR BT and positive nodes correlated with } \\
\text { worse bFFS } \\
\text { bFFS was } 73.9 \% \text { for patients within EAU guidelines vs } \\
11.6 \% \text { outside EAU guidelines }\end{array}$ & \\
\hline $\begin{array}{l}\text { Sanderson et } \\
\text { al }^{20} \\
2006 \\
\mathrm{~N}=51,33 \text { with } \\
\text { questionnaire }\end{array}$ & $\begin{array}{l}\text { Single center } \\
\text { retrospective case } \\
\text { series + questionnaire } \\
1983-2002\end{array}$ & $\begin{array}{l}\text { Median Age } 65 \\
\text { Median Pre-SRP PSA } 8.0 \mathrm{ng} / \mathrm{mL} \\
\text { Some patients received neoadjuvant } \\
\text { ADT, post op ADT, orchiectomy. } \\
\text { Median FU } 7.2 \text { yrs }\end{array}$ & SRP & $\begin{array}{l}\text { PFS: } 47 \% \text { at } 5 \text { yrs overall } \\
\text { Median OS was } 12.9 \text { yrs } \\
\text { PFS was } 100 \%, 80 \% \text { and } 67 \% \text { for patients with pT2N0, } \\
\text { preop PSA }<=5.0 \text { or Gleason }</=7 \text { respectively at } 5 \text { yrs. } \\
\text { Pre-salvage PSA predictive of OS }\end{array}$ & $\begin{array}{l}\text { QOL (median age } 72 \text { and median } 7.5 \text { years } \\
\text { after surgery) } \\
\text { Total continence or occasional dribbling } \\
\text { reported by } 82 \% \text { with and } 69 \% \text { without AUS } \\
\text { device } \\
\text { Overall, } 73 \% \text { characterized overall urinary } \\
\text { function as "small" "very small" or "no" } \\
\text { problem. } \\
\text { Mean sexual function score was clinically } \\
\text { significantly higher for inflatable penile } \\
\text { prosthesis (IPP) patients while patients with } \\
\text { nerve sparing technique did worse than IPP } \\
\text { patients but better than standard SRP patients }\end{array}$ \\
\hline $\begin{array}{l}\text { Ward et al. }{ }^{21} \\
2005 \\
\mathrm{~N}=199\end{array}$ & $\begin{array}{l}\text { Single Center, } \\
\text { retrospective case } \\
\text { series } \\
1967-2000\end{array}$ & $\begin{array}{l}\text { Life expectancy }>/=10 \text { years, all with } \\
\text { positive prostate biopsy, no metastatic } \\
\text { disease. } \\
\text { Median age: } 65 \text { years } \\
\text { Mean Preop PSA } 8.5 \mathrm{ng} / \mathrm{mL} \\
\text { Median FU } 7.0 \mathrm{yrs}\end{array}$ & $\begin{array}{l}\text { SRP or salvage } \\
\text { cystoprostatectomy } \\
\text { (SCP) }\end{array}$ & $\begin{array}{l}\text { PFS: } 67 \%, 58 \% \text {, and } 48 \% \text { at } 3,5 \text {, and } 10 \text { years. } \\
\text { CSS: } 87 \%, 79 \% \text {, and } 65 \% \text { at } 3,5 \text {, and } 10 \text { years } \\
\text { Patients undergoing SRP did better than those requiring } \\
\text { SCP: Median PFS of } 8.7 \text { vs } 4.4 \text { years. } \\
\text { Aneuploidy was strongest predictor of PFS } \\
\text { Pathological stage was strongest predictor of CSS }\end{array}$ & $\begin{array}{l}\text { Intraop rectal injury in } 4 \% \text { of SRP and } 10 \% \\
\text { SCP. } \\
\text { Complete continence maintained in } 52 \% \\
\text { Less overall morbidity in surgeries performed } \\
\text { after } 1990 \text { as opposed to before }\end{array}$ \\
\hline \multicolumn{6}{|c|}{ Low Dose Rate Brachytherapy (LDR BT) } \\
\hline $\begin{array}{l}\text { Crook et al. }{ }^{26} \\
2019 \\
\mathrm{~N}=92\end{array}$ & $\begin{array}{l}\text { Prospective phase II } \\
\text { study across } 20 \text { sites } \\
\text { in the US and Canada } \\
2007-2014\end{array}$ & $\begin{array}{l}\text { Initial Tx: EBRT alone } \\
\text { Median age: } 70 \text { years } \\
\text { Positive biopsy }>30 \text { months after initial } \\
\text { tx. } \\
\text { PSA }<10 \mathrm{ng} / \mathrm{mL} \\
\text { Gleason } 7(48 \%) \text { all others Gleason } 2-6 \\
{ }^{99} \text { Tc bone scan and abdominal/pelvic } \\
\text { CT showed no regional/distance disease } \\
\text { Median FU: } 4.5 \text { yrs }\end{array}$ & $\begin{array}{l}\text { LDR BT } \\
\text { 125-I 140 Gy or } \\
\text { 103-Pd } 120 \text { Gy }\end{array}$ & & $\begin{array}{l}\text { Late grade } 3 \text { treatment related GI/GU adverse } \\
\text { events experienced by } 14 \% \text { of patients. } \\
\text { No late grade } 4 \text { or } 5 \text { events reported. } \\
\text { Only V100 (volume receiving } 100 \% \text { of the } \\
\text { prescribed dose) was predictive of late } \mathrm{GI} / \mathrm{GU} \\
\text { adverse events (OR } 1.24 ; \mathrm{p}=0.03 \text { ). } \\
\text { Early grade } 3 \text { treatment related } \mathrm{GI} / \mathrm{GU} \text { adverse } \\
\text { events experienced by } 14 \% \text { of patients. } \\
\text { No early grade } 4 \text { or } 5 \text { events reported. } \\
\text { Half of patients with early grade } 3 \text { adverse } \\
\text { events developed late grade } 3 \text { adverse events. }\end{array}$ \\
\hline
\end{tabular}




\begin{tabular}{|c|c|c|c|c|c|}
\hline & & & & & $\begin{array}{l}\text { The authors conclude that LDR BT after EBRT } \\
\text { failure has acceptable tolerance. }\end{array}$ \\
\hline $\begin{array}{l}\text { Vargas et al. } .^{22} \\
2014 \\
\mathrm{~N}=69\end{array}$ & $\begin{array}{l}\text { Single institution } \\
\text { retrospective case } \\
\text { series } \\
1989-2011\end{array}$ & $\begin{array}{l}\text { Initial Tx: EBRT alone } \\
\text { Average Age: } 72.5 \text { years } \\
\text { Positive biopsy more than } 2 \text { years after } \\
\text { initial tx } \\
\text { PSA }>5 \mathrm{ng} / \mathrm{mL} \text { while on HT were } \\
\text { considered castration resistant prostate } \\
\text { cancer (CRPC) } \\
\text { Androgen suppression was used in } 89 \% \\
\text { of cases neoadj and adjuvantly } \\
\text { Median FU } 5.0 \text { yrs }\end{array}$ & $\begin{array}{l}\text { LDR BT } \\
103-P d 100 \text { Gy }\end{array}$ & $\begin{array}{l}\text { bFFS: } 73.8 \% \text { in non-castration resistant disease vs } 20 \% \text { in } \\
\text { castration resistant patients at } 5 \text { yrs } \\
\text { MFS: } 90 \% \text { at } 5 \text { yrs } \\
\text { OS: } 64 \% \text { at } 5 \text { yrs } \\
\text { Excluding CRPC patients (n=60) } 5 \text { year bFFS was } 85.6 \% \text {, } \\
74.8 \% \text {, and } 66 \% \text { for low, intermediate, and high risk } \\
\text { patients respectively. } \\
5 \text { year bFFS was } 77.7 \% \text { and } 43.3 \% \text { without and with } \\
\text { treatment delay as defined as receiving } 6 \text { months of ADT } \\
\text { prior to salvage BT }\end{array}$ & \\
\hline $\begin{array}{l}\text { Grado et al. }{ }^{24} \\
1999 \\
\mathrm{~N}=49\end{array}$ & $\begin{array}{l}\text { Mayo Clinic } \\
\text { Scottsdale } \\
\text { retrospective case } \\
\text { series } \\
1990-1996\end{array}$ & $\begin{array}{l}\text { Median age: } 73.3 \\
\text { Initial tx: } 46 \text { EBRT, } 3 \mathrm{BT} \\
\text { PreSalvage PSA: } 5.6 \mathrm{ng} / \mathrm{mL} \text { (not } \\
\text { including patients with neoadj ADT or } \\
\text { prior orchiectomy } \\
11 \text { patients had already failed additional } \\
\text { modality and } 2 \text { had failed two } \\
\text { additional modalities. } \\
\text { One patient had mets while } 48 \text { had no } \\
\text { evidence of mets at time of salvage } \\
\text { Median FU } 5.3 \text { yrs }\end{array}$ & $\begin{array}{l}\text { LDR BT ( } 37 \\
\text { patients with Pd103 } \\
\text { median } 120 \mathrm{~Gy} \text { and } \\
12 \text { with } \mathrm{I125} \\
\text { median } 160 \mathrm{~Gy} .) \\
4 \text { received } \\
\text { adjunctive radiation } \\
\text { therapy and } 8 \\
\text { received neoadj } \\
\text { hormone therapy }\end{array}$ & $\begin{array}{l}\text { bFFS: } 48 \% \text { at } 3 \text { yrs, } 34 \% \text { at } 5 \text { yrs } \\
\text { CSS: } 89 \% \text { at } 5 \text { yrs, } 79 \% \text { at } 5 \mathrm{yrs} \\
\text { OS: } 75 \% \text { at } 3 \text { yrs, } 56 \% \text { at } 5 \text { yrs } \\
\text { Post-Salv PSA nadir of }<0.5 \mathrm{ng} / \mathrm{mL} \text { associated with } \\
\text { improved bFFS (RR } 4.25 \text { for patients with } 0.5 \mathrm{ng} / \mathrm{mL} \text { or } \\
\text { more) }\end{array}$ & $\begin{array}{l}\text { Acute Complications: frequency, urgency, } \\
\text { hesitancy, nocturia common during first } 3 \\
\text { months but transient and managed with alpha- } \\
\text { blocker } \\
\text { Sexual Side effects: Only } 1 \text { patient reported } \\
\text { decreased capacity for sexual activity after } \\
\text { salvBT but } 60 \% \text { of patients were not sexually } \\
\text { active prior to salvage. }\end{array}$ \\
\hline $\begin{array}{l}\text { Burri et al. }{ }^{25} \\
2010 \\
\mathrm{~N}=37\end{array}$ & $\begin{array}{l}\text { Mount Sinai single } \\
\text { center retrospective } \\
\text { case series } \\
1994-2008\end{array}$ & $\begin{array}{l}\text { Median age at salvage: } 70 \\
\text { Median PSA at salvage: } 5.6 \mathrm{ng} / \mathrm{mL} \\
\text { Initial tx: } 32 \text { EBRT, } 5 \text { BT } \\
\text { Median FU } 7.2 \text { yrs }\end{array}$ & $\begin{array}{l}\text { LDR BT (Pd103 } \\
110 \mathrm{~Gy}, \mathrm{I} 125 \\
135 \mathrm{~Gy})\end{array}$ & $\begin{array}{l}\text { bFFS: } 65 \% \text { at } 5 \text { yrs, } 54 \% \text { at } 10 \mathrm{yrs} \\
\text { LRFS: } 84 \% \text { at } 5 \text { yrs, } 76 \% \text { at } 10 \mathrm{yrs} \\
\text { DMFS: } 94 \% \text { at } 5 \text { yrs, } 79 \% \text { at } 10 \mathrm{yrs} \\
\text { CSS: } 96 \% \text { at } 5 \text { yrs, } 96 \% \text { at } 10 \mathrm{yrs} \\
\text { OS: } 94 \% \text { at } 5 \text { yrs, } 74 \% \text { at } 10 \mathrm{yrs}\end{array}$ & \\
\hline $\begin{array}{l}\text { Moman et al. }{ }^{27} \\
2010 \\
\mathrm{~N}=31\end{array}$ & $\begin{array}{l}\text { Single center } \\
\text { Retrospective case } \\
\text { series } \\
1994-2009\end{array}$ & $\begin{array}{l}\text { Initial Tx: } 20 \text { EBRT and } 11125-\mathrm{I} \\
\text { Mean age } 69.3 \text { years } \\
\text { Mean pre-Salv PSA } 11.4 \mathrm{ng} / \mathrm{mL} \\
\text { With mean doubling time of } 13 \text { months } \\
\text { Median FU } 9.0 \text { years }\end{array}$ & $\begin{array}{l}\text { LDR BT } \\
125-\mathrm{I} 145 \mathrm{~Gy}\end{array}$ & $\begin{array}{l}\text { bFFS: } 51 \% \text { at } 1 \text { yr, } 20 \% \text { at } 5 \text { yrs } \\
\text { CSS: } 74 \% \text { at } 5 \text { yrs, } 46 \% \text { at } 10 \mathrm{yrs} \\
\text { OS: } 72 \% \text { at } 5 \text { yrs, } 39 \% \text { at } 10 \mathrm{yrs} \\
\text { Gleason }>7 \text { had HR } 12.4 \text { for BCR compared to Gleason } \\
\leq 7\end{array}$ & $\begin{array}{l}\text { GU Toxicity: } 87 \% \text { and } 55 \% \text { of patients had } \\
\text { grade } 1-2 \text { toxicity in acute }(<90 \text { days) and late } \\
\text { phase ( }>90 \text { days) respectively. Grade } 3 \text { toxicity } \\
\text { occurred in } 19 \% \text { in late phase } \\
\text { GI Toxicity: } 55 \% \text { and } 51 \% \text { of patients had } \\
\text { grade } 1-2 \text { toxicity in acute and late phase } \\
\text { respectively. Grade } 3 \text { toxicity occurred in } 6 \% \text { in } \\
\text { late phase. }\end{array}$ \\
\hline $\begin{array}{l}\text { Baumann et al. }{ }^{23} \\
2017 \\
\mathrm{~N}=33\end{array}$ & $\begin{array}{l}\text { US retrospective case } \\
\text { series } \\
1998-2013\end{array}$ & $\begin{array}{l}\text { Initial Tx: EBRT } \\
\text { Median age: } 75 \text { years } \\
\text { Median pre-salvage PSA } 5.0 \mathrm{ng} / \mathrm{mL} \\
\text { High risk disease in } 55 \% \text { of patients } \\
\text { Median FU: } 5.1 \text { yrs }\end{array}$ & $\begin{array}{l}\text { LDR BT 103-Pd } \\
100 \mathrm{~Gy}(\mathrm{~N}=25) \text { or } \\
\text { HDR BT } 30 \mathrm{~Gy} \text { in } \\
6 \text { fractions }(\mathrm{N}=8) \\
\text { All received 4-6 } \\
\text { months neoadjuvant } \\
\text { plus adjuvant ADT }\end{array}$ & $\begin{array}{l}\text { Relapse free survival: } 79 \% \text { at } 5 \mathrm{yrs}, 67 \% \text { at } 7 \text { yrs } \\
\text { DMFS: } 93 \% \text { at } 5 \text { yrs, } 86 \% \text { at } 7 \text { yrs } \\
\text { OS: } 94 \% \text { at } 5 \text { yrs, } 85 \% \text { at } 7 \text { yrs } \\
\text { Age at diagnosis, PSA nadir after EBRT, age at } \\
\text { recurrence, and presalvage PSA were significant } \\
\text { predictors of relapse free survival after salvage. }\end{array}$ & $\begin{array}{l}\text { Late grade } 3 \mathrm{GU} \text { toxicity occurred in } 12 \% \text { of } \\
\text { patients with resolution or significant } \\
\text { improvement } 3 \text { of } 4 \text { of these cases. } \\
1 \text { patient experienced late grade } 1 \text { GI toxicity } \\
\text { but no other cases of GI toxicity were reported. } \\
\text { ADT resulted in grade } 2 \text { endocrine toxicity in } \\
30 \% \text { of patients. }\end{array}$ \\
\hline \multicolumn{6}{|c|}{ High Dose Rate Brachytherapy (HDR BT) } \\
\hline $\begin{array}{l}\text { Chen et al. }{ }^{28} \\
2013 \\
\mathrm{~N}=52\end{array}$ & $\begin{array}{l}\text { Single institution } \\
\text { retrospective case } \\
\text { series } \\
1998-2009\end{array}$ & $\begin{array}{l}77 \% \text { patients had increase in Gleason } \\
\text { score at recurrence vs primary tx. } \\
\text { Median age: } 67.5 \\
\text { Median PSA } 5.0 \mathrm{ng} / \mathrm{mL}\end{array}$ & $\begin{array}{l}\text { HDR BT } \\
36 \text { Gy in } 6 \text { fractions } \\
\text { in } 2 \text { separate } \\
\text { implants performed } \\
\text { 1 week apart }\end{array}$ & $\begin{array}{l}\text { bFFS: } 51 \% \text { at } 5 \text { yrs } \\
\text { OS: } 92 \% \text { at } 5 \text { yrs } \\
\text { No significant predictors of biochemical control }\end{array}$ & $\begin{array}{l}\text { GU Toxicity: } 2 \% \text { of patients had grade } 3 \\
\text { toxicity. No grade } 4 \text { or } 5 . \\
\text { GI: No grade } 3 \text { or higher acute or late GI } \\
\text { toxicity. Late grade } 2 \mathrm{GI} \text { in } 4 \%\end{array}$ \\
\hline
\end{tabular}




\begin{tabular}{|c|c|c|c|c|c|}
\hline & & Median FU 5.0 yrs & & & \\
\hline $\begin{array}{l}\text { Yamada et al. }{ }^{29} \\
2014 \\
\mathrm{~N}=42\end{array}$ & $\begin{array}{l}\text { Prospective phase II } \\
\text { study } \\
2007-2011\end{array}$ & $\begin{array}{l}\text { Biopsy proven recurrence after } \\
\text { definitive EBRT } \\
\text { Median age: } 72 \\
\text { Median presalv PSA: } 3.5 \mathrm{ng} / \mathrm{mL} \\
18 \text { patients had ADT presalvage but all } \\
\text { discontinued after HDR BT } \\
\text { Excluded: any patient with PSA } \\
>10 \mathrm{ng} / \mathrm{mL} \text { at assignment and } \\
\text { international prostate symptom score } \\
\text { IPSS >15 before salvage therapy. Hx of } \\
\text { inflammatory bowel disease, prior } \\
\text { rectal surgery. Abnormal coag studies. } \\
\text { Median FU } 3.0 \text { yrs }\end{array}$ & $\begin{array}{l}\text { HDR BT } \\
\text { 192-Ir } 32 \text { Gy in } 4 \\
\text { fractions in } 1 \\
\text { implant }\end{array}$ & $\begin{array}{l}\text { bFFS: } 68.5 \% \text { at } 5 \text { yrs } \\
\text { DMFS: } 81.5 \% \text { at } 5 \text { yrs } \\
\text { OS: } 79 \% \text { at } 5 \text { yrs }\end{array}$ & $\begin{array}{l}\text { GU Toxicity: Acute Grade } 1 \text { and Grade } 2: 38 \% \\
\text { and } 40 \% \text {. Late Grade } 1 \text { and Grade } 2: 48 \% \text { and } \\
48 \% .3 \text { total Grade } 3 \text { events but no Grade } 4 \text { or } \\
\text { greater. } \\
\text { GI: Late Grade } 1 \text { and Grade } 2 \text { GI toxicity } 43 \% \\
\text { and } 14 \% \text { without Grade } 3 \text { or higher. Most GI } \\
\text { complications consisted of transient rectal } \\
\text { bleeding. }\end{array}$ \\
\hline \multicolumn{6}{|c|}{ Salvage Cryotherapy (SC) } \\
\hline $\begin{array}{l}\text { Pisters et al. } .^{30} \\
1997 \\
\mathrm{~N}=150\end{array}$ & $\begin{array}{l}\text { MD Anderson } \\
\text { retrospective case } \\
\text { series } \\
1992-1995\end{array}$ & $\begin{array}{l}\text { Median age } 68.8 \text { years } \\
\text { 91\% Caucasian } \\
\text { Initial Tx: } \\
\text {-Group 1: RT only (98 EBRT only, } 4 \\
\text { LDR BT only, } 8 \text { EBRT and LDR BT.) } \\
\text {-Group 2: Combination of therapies } \\
\text { (27 EBRT + HT, } 6 \text { EBRT + HT+CT, } 1 \\
\text { EBRT + CT, } 4 \text { HT only, } 2 \text { HT + CT) } \\
\text { Mean FU } 1.4 \text { yrs }\end{array}$ & SC & $\begin{array}{l}\text { bFFS: } 42 \% \text { overall } \\
\text { Among group } 1 \text { patients, BCR was more prevalent in } \\
\text { patients who received only one freeze-thaw cycle } \\
\text { compared to two. Also the negative biopsy rate after } \\
\text { double freeze-thaw cycle was } 93 \% \text { compared to } 71 \% \text { for } \\
\text { single cycle. }\end{array}$ & $\begin{array}{l}\text { Urinary incontinence reported in } 73 \% \text {, } \\
\text { obstructive symptoms in } 67 \% \text {, impotence in } \\
72 \% \text {, and severe perineal pain in } 8 \% \text {. }\end{array}$ \\
\hline $\begin{array}{l}\text { Wenske et al. }{ }^{32} \\
2013 \\
\mathrm{~N}=328\end{array}$ & $\begin{array}{l}\text { Columbia University } \\
\text { NYC retrospective } \\
\text { case series } \\
1994-2011\end{array}$ & $\begin{array}{l}\text { Median Age } 65.8 \text { years } \\
\text { Median Presalv PSA } 4.0 \mathrm{ng} / \mathrm{mL} \\
\text { Median time to SC } 67.5 \mathrm{mo} \text { after } \\
\text { primary RT or cryosurgery } \\
\text { Initial tx: } 259 \text { EBRT, } 49 \text { LDR BT, } 20 \\
\text { cryosurgery } \\
\text { Median FU } 4.0 \text { yrs }\end{array}$ & $\mathrm{SC}$ & $\begin{array}{l}\text { bFFS: } 63 \% \text { at } 5 \mathrm{yrs}, 35 \% \text { at } 10 \mathrm{yrs} \\
\text { CSS: } 91 \% \text { at } 5 \mathrm{yrs}, 79 \% \text { at } 10 \mathrm{yrs} \\
\text { OS: } 74 \% \text { at } 5 \mathrm{yrs}, 45 \% \text { at } 10 \mathrm{yrs} \\
\text { PSA nadir after SC was predictive of bFFS and CSS. }\end{array}$ & $\begin{array}{l}\text { Urethral stricture requiring intervention in } \\
4.6 \% \text {, bladder outlet obstruction requiring } \\
\text { intervention in } 3.4 \% \text {. Rectourethral or } \\
\text { urethroperineal fistula formation in } 1.8 \% \text {. } \\
55 \text { of the patients underwent focal SC of } \\
\text { affected lobe. Overall Survival was better for } \\
\text { this cohort but rectourethral fistula formation } \\
\text { occurred in } 5.5 \%\end{array}$ \\
\hline $\begin{array}{l}\text { Williams et al. } \\
2011 \\
\mathrm{~N}=176 \text { of } 187\end{array}$ & $\begin{array}{l}\text { Canadian } \\
\text { retrospective case } \\
\text { series } \\
1995-2004\end{array}$ & $\begin{array}{l}\text { Median age: } 70.9 \text { years } \\
\text { Median presalvage PSA: } 4.9 \mathrm{ng} / \mathrm{mL} \\
71 \% \text { had neoadjuvant ADT for } 3-6 \\
\text { months for downsizing } \\
\text { Initial tx: } 183 \text { EBRT, } 3 \text { BT, } 1 \\
\text { EBRT+BT. } \\
\text { Mean FU } 7.5 \mathrm{yrs}\end{array}$ & $\mathrm{SC}$ & $\begin{array}{l}\text { DFS (recurrence including BCR): } 47 \%, 39 \% \text {, and } 39 \% \text { at } \\
5,8,10 \text { yrs } \\
\text { MFS: } 87 \%, 83 \%, 82 \% \text { at } 5,8,10 \mathrm{yrs} \\
\text { OS: } 95 \%, 91 \% \text { and } 87 \% \text { and } 5,8 \text {, and } 10 \text { yrs } \\
\text { Post salvage nadir }>1 \text { had RR } 6.63 \text { for recurrence } p<0.001 \\
\text { Presalvage PSA }<5 \mathrm{ng} / \mathrm{mL} \text { had DFS } 64 \% \text { at } 10 \text { years as } \\
\text { opposed to } 6.7 \% \text { with PSA }>10 \mathrm{ng} / \mathrm{mL} \\
\text { Pres-alvage Gleason and pre-intial tx PSA both also } \\
\text { correlated with DFS }\end{array}$ & \\
\hline $\begin{array}{l}\text { Perrotte et al. }{ }^{34} \\
1999 \\
\mathrm{~N}=112 \text { of } 150\end{array}$ & $\begin{array}{l}\text { MD Anderson cross } \\
\text { sectional study of } \\
\text { quality of life } \\
1992-1999\end{array}$ & $\begin{array}{l}\text { Median age } 68.8 \text { years } \\
\text { 91\% Caucasian } \\
\text { Initial Tx: } \\
\text {-Group 1: RT only (98 EBRT only, } 4 \\
\text { LDR BT only, } 8 \text { EBRT and LDR BT.) }\end{array}$ & $\mathrm{SC}$ & & $\begin{array}{l}\text { Incontinence: } 72 \% \text { report dribbling or leakage } \\
\text { of urine } \\
\text { Voiding Symptoms: Medium to severe } \\
\text { symptoms in } 66 \% \text { of patients. More cases of } \\
\text { voiding symptoms without use of urethral } \\
\text { warming catheter ( } 93 \% \text { vs } 55 \% \text { of patients) }\end{array}$ \\
\hline
\end{tabular}




\begin{tabular}{|c|c|c|c|c|c|}
\hline & & $\begin{array}{l}\text {-Group 2: Combination of therapies } \\
\text { (27 EBRT + HT, } 6 \text { EBRT + HT+CT, } 1 \\
\text { EBRT + CT, } 4 \text { HT only, } 2 \text { HT + CT) } \\
\text { Mean FU } 1.4 \text { yrs }\end{array}$ & & & $\begin{array}{l}\text { Sexual Function: } 41 \% \text { of patients were potent } \\
\text { prior to SC down to } 15 \% \text { after tx. Double } \\
\text { freeze-thaw cycle group had significantly worse } \\
\text { potency after tx ( } 8 \% \text { vs } 23 \% \text { ) } \\
\text { Pain: } 44 \% \text { report some degree of chronic } \\
\text { perineal pain or discomfort. } 70 \% \text { vs } 34 \% \text { had } \\
\text { pain with vs without urethral warming catheter. } \\
33 \% \text { overall satisfaction rate with SC }\end{array}$ \\
\hline $\begin{array}{l}\text { Ng et al. } \\
2007 \\
\mathrm{~N}=187\end{array}$ & $\begin{array}{l}\text { Canadian } \\
\text { retrospective case } \\
\text { series } \\
1995-2004\end{array}$ & $\begin{array}{l}\text { Median age: } 70.9 \text { years } \\
\text { Median presalvage PSA: } 4.9 \mathrm{ng} / \mathrm{mL} \\
71 \% \text { had neoadjuvant ADT for 3-6 } \\
\text { months for downsizing } \\
\text { Initial tx: } 183 \text { EBRT, } 3 \text { BT, } 1 \\
\text { EBRT+BT. } \\
\text { Mean FU } 3.3 \mathrm{yrs}\end{array}$ & $\mathrm{SC}$ & $\begin{array}{l}\text { bFFS: } 56 \% \text { in patients with pre-salvage PSA } \leq 4 \mathrm{ng} / \mathrm{mL} \text {, } \\
29 \% \text { with PSA } 4-9.99 \mathrm{ng} / \mathrm{mL} \text {, and } 14 \% \text { with PSA } \geq 10 \\
\mathrm{ng} / \mathrm{mL} \text { at } 5 \text { yrs. } \\
\text { OS: } 97 \% \text { at } 5 \text { yrs, } 92 \% \text { at } 8 \mathrm{yrs}\end{array}$ & $\begin{array}{l}8 \% \text { of patients needed additional surgery for } \\
\text { complications }\end{array}$ \\
\hline \multicolumn{6}{|c|}{ High Intensity Focused Ultrasound (HIFU) } \\
\hline $\begin{array}{l}\text { Crouzet et al. }{ }^{38} \\
2017 \\
\mathrm{~N}=418\end{array}$ & $\begin{array}{l}\text { International } \\
\text { retrospective case } \\
\text { seriers } \\
1995-2009\end{array}$ & $\begin{array}{l}\text { Mean time between initial tx and } \\
\text { salvage: } 5.1 \text { years } \\
\text { Mean age } 68.6 \text { years } \\
\text { Mean pre-salvage PSA } 6.8 \mathrm{ng} / \mathrm{mL} \\
191 \text { patients had hx of ADT but none } \\
\text { continued after HIFU. } \\
87.1 \% \text { of patients had one session of } \\
\text { HIFU while } 12.2 \% \text { and } 0.7 \% \text { had two } \\
\text { and three session respectively } \\
\text { Median FU } 3.3 \text { yrs }\end{array}$ & HIFU & $\begin{array}{l}\text { bFFS: } 49 \% \text { at } 5 \text { yrs overall. } 58 \%, 51 \% \text {, and } 36 \% \text { for pre- } \\
\text { EBRT low, intermediate, and high risk patients or } 67 \% \text {, } \\
42 \% \text {, and } 22 \% \text {, for pre-S-HIFU PSA levels of } \leq 4,4-10 \\
\text { and } 10 \mathrm{ng} / \mathrm{mL} \text { respectively. } \\
\text { MFS: } 81 \% \text { at } 7 \text { yrs } \\
\text { CSS: } 82 \% \text { at } 7 \text { yrs } \\
\text { OS: } 72 \% \text { at } 7 \text { yrs } \\
\text { Lower PSA nadir after S-HIFU correlated with decreased } \\
\text { need for ADT after salvage. }\end{array}$ & \\
\hline $\begin{array}{l}\text { Gelet et al. } \\
2004 \\
\mathrm{~N}=71\end{array}$ & $\begin{array}{l}\text { Single center French } \\
\text { retrospective case } \\
\text { series } \\
1995-2003\end{array}$ & $\begin{array}{l}\text { No staging pre-HIFU } \\
\text { Median presalv PSA } 5.7 \mathrm{ng} / \mathrm{mL} \\
\text { Mean age } 67 \\
\text { Mean } 1.2 \mathrm{yrs}\end{array}$ & HIFU & $\begin{array}{l}\text { DFS: } 38 \% \text { at } 2.5 \text { yrs } \\
\text { Negative biopsy rate of } 73 \% \text { at } 2.5 \mathrm{yrs} \\
\text { Metastasis observed in } 12.7 \% \text { overall }\end{array}$ & $6 \%$ developed urethrorectal fistula \\
\hline $\begin{array}{l}\text { Kanthabalan et } \\
\text { al. } 40 \\
2017 \\
\mathrm{~N}=150\end{array}$ & $\begin{array}{l}\text { UK retrospective } \\
\text { case series } \\
2006-2015\end{array}$ & $\begin{array}{l}\text { Mean age: } 69.8 \text { years } \\
\text { Mean pre-salvage PSA } 5.5 \\
45.3 \% \text { with pre-salvage ADT } \\
\text { Median FU } 2.9 \text { yrs } \\
\end{array}$ & HIFU & $\begin{array}{l}\text { bFFS: } 48 \% \text { at } 3 \text { yrs overall. } 100 \%, 61 \% \text {, and } 32 \% \text { at } 3 \text { yrs } \\
\text { for low intermediate and high risk groups. } \\
\text { OS: } 92 \% \text { at } 5 \text { yrs }\end{array}$ & \\
\hline $\begin{array}{l}\text { Ahmed et al. }{ }^{41} \\
2012 \\
\mathrm{~N}=84\end{array}$ & $\begin{array}{l}\text { Two site } \\
\text { international } \\
\text { retrospective case } \\
\text { series } \\
2004-2009\end{array}$ & $\begin{array}{l}\text { Mean age } 68.3 \\
\text { Median Presalv PSA } 3.8 \mathrm{ng} / \mathrm{mL} \\
\text { Initial Tx: all EBRT } \\
\text { Gleason 6-7 only } \\
\text { Median FU } 1.7 \text { yrs }\end{array}$ & HIFU & $\begin{array}{l}\text { PFS: } 59 \% \text { at } 1 \mathrm{yr}, 43 \% \text { at } 2 \mathrm{yrs} \\
8 \% \text { of patients did not respond to therapy and had } \\
\text { increased PSA after therapy } \\
25 \% \text { of whole cohort and } 43 \% \text { of those biopsied had } \\
\text { residual disease on biopsy following salvage HIFU }\end{array}$ & \\
\hline $\begin{array}{l}\text { Crouzet et al. }{ }^{42} \\
2012 \\
\mathrm{~N}=290\end{array}$ & $\begin{array}{l}\text { French retrospective } \\
\text { case series } \\
1995-2009\end{array}$ & $\begin{array}{l}\text { Mean age } 68.7 \\
\text { Mean PSA } 6.38 \mathrm{ng} / \mathrm{mL} \\
\text { D'Amico risk group: } 19 \% \text { low risk, } \\
31.4 \% \text { intermediate, and } 43 \% \text { high risk } \\
\text { and undefined in } 6.6 \% \\
\text { Mean time from Initial tx to salvage } \\
\text { was } 60 \text { months } \\
50 \% \text { received ADT prior to salvage at } \\
\text { some point }\end{array}$ & HIFU & $\begin{array}{l}\text { PFS: } 45 \%, 31 \% \text {, and } 21 \% \text { at } 5 \text { yrs for low, intermediate, } \\
\text { and high risk groups } \\
\text { MFS: } 80 \% \text { at } 5 \text { yrs, } 79.5 \% \text { at } 7 \text { yrs } \\
\text { Increased risk of progression with higher pre-salvage } \\
\text { PSA, previous ADT, and Gleason } \geq 8 \text { vs Gleason } \leq 6\end{array}$ & $\begin{array}{l}6 \text { cases of urethrorectal fistula, } 8 \text { cases of pubic } \\
\text { bone osteitis. } 16 \% \text { experienced bladder outlet } \\
\text { obstruction. }\end{array}$ \\
\hline
\end{tabular}




\begin{tabular}{|c|c|c|c|c|c|}
\hline & & $\begin{array}{l}\text { Median FU } 2.3 \text { yrs for PFS and } 4.0 \text { yrs } \\
\text { for CSS and MFS }\end{array}$ & & & \\
\hline \multicolumn{6}{|c|}{ Stereotactic Body Radiation Therapy (SBRT) } \\
\hline $\begin{array}{l}\text { Fuller et al. }{ }^{44} \\
2015 \\
\mathrm{~N}=29\end{array}$ & $\begin{array}{l}\text { Prospective single } \\
\text { arm study } \\
2009-2014\end{array}$ & $\begin{array}{l}\text { At least } 2 \text { years since prior RT } \\
\text { Median age } 73 \\
\text { Median presalv PSA } 3.1 \mathrm{ng} / \mathrm{mL} \\
\text { Median interval between initial tx and } \\
\text { salvage } 88 \text { months } \\
\text { Initial tx: } 27 \text { EBRT, } 1 \mathrm{BT}, 1 \mathrm{SBRT} \\
7 \text { on } \mathrm{ADT} \text { at time of initial failure but } \\
\text { none received neoadj or adjuvant ADT } \\
\text { Median FU } 2.0 \text { yrs }\end{array}$ & $\begin{array}{l}\text { SBRT } \\
34 \text { Gy in } 5 \text { fractions }\end{array}$ & bFFS: $82 \%$ at 2 yrs & $\begin{array}{l}\text { GU Toxicity: } 18 \% \text { report } \geq \text { grade } 2 \text { with one } \\
\text { case of grade } 3 \text { and one case of grade } 4 \text {. } \\
\text { GI Toxicity: No acute or late GI toxicity greater } \\
\text { than grade } 1 \\
\text { Sexual function: Data available on } 10 \text { patients } \\
\text { who were potent before salvage tx. Three } \\
\text { patients had a major decrease in potency while } \\
\text { four had no significant change. (SHIM scoring) }\end{array}$ \\
\hline $\begin{array}{l}\text { Leroy et al. }{ }^{45} \\
2017 \\
\mathrm{~N}=23\end{array}$ & $\begin{array}{l}\text { Retrospective single } \\
\text { institution case series } \\
\text { 2011-2014 }\end{array}$ & $\begin{array}{l}\text { Median age } 70 \text { yrs } \\
\text { Initial tx with EBRT or BT }+/ \text { - ADT } \\
\text { Median pre-salvage PSA } 2.5 \mathrm{ng} / \mathrm{mL} \\
\text { Recurrence at least } 2 \text { yr after initial tx } \\
\text { Median FU } 1.9 \text { yrs }\end{array}$ & $\begin{array}{l}\text { SBRT } \\
36 \text { Gy in } 6 \text { fractions }\end{array}$ & $\begin{array}{l}\text { DFS: } 54 \% \text { at } 2 \text { yrs } \\
\text { OS: } 100 \% \text { at } 2 \text { yrs } \\
\text { LRFS: } 76 \% \text { at } 2 \text { yrs }\end{array}$ & $\begin{array}{l}\text { Grade } 3 \text { toxicity in } 9 \% \text { of patients (cystitis and } \\
\text { neuralgia) } \\
\text { Grade } 1-2 \text { urinary toxicity was common } \\
\text { No grade } 4 \text { or higher toxicity reported }\end{array}$ \\
\hline \multicolumn{6}{|c|}{ Oligometastatic Disease } \\
\hline $\begin{array}{l}\text { Ost et al. }^{46} \\
2017 \\
\mathrm{~N}=62\end{array}$ & $\begin{array}{l}\text { Multicenter, } \\
\text { randomized, phase II } \\
\text { study } \\
2012-2015\end{array}$ & $\begin{array}{l}\text { Median age } 64 \text { (surveillance) and } 62 \\
\text { (MDT) yrs } \\
\text { Median PSA at inclusion was } 3.8 \\
\text { ng/mL for surveillance and } 5.3 \text { for } \\
\text { MDT } \\
\text { One metastasis in } 29 \% \text { of surveillance } \\
\text { group vs } 58 \% \text { of MDT group } \\
\text { Median FU } 3 \text { yrs }\end{array}$ & $\begin{array}{l}\text { Metastasis directed } \\
\text { therapy (MDT) } \\
\text { with SBRT or } \\
\text { surgery vs } \\
\text { Surveillance for } \\
\text { oligometastasis }\end{array}$ & $\begin{array}{l}\text { Median ADT-free survival was } 13 \text { months for surveillance } \\
\text { group and } 21 \text { months for MDT group. } \\
\text { Local progression in } 6 \text { of surveillance group versus none } \\
\text { of the MDT group. } \\
\text { PSA decline observed in } 35 \% \text { for surveillance group } \\
\text { versus } 75 \% \text { in MDT group. }\end{array}$ & $\begin{array}{l}\text { Grade } 1 \text { toxicity in } 17 \% \text { of the MDT patients } \\
\text { without grade } 2 \text { or higher events. } \\
\text { No difference in quality of life between the two } \\
\text { groups }\end{array}$ \\
\hline $\begin{array}{l}\text { Ingrosso et al. }{ }^{47} \\
2016 \\
\mathrm{~N}=40\end{array}$ & $\begin{array}{l}\text { Italian retrospective } \\
\text { case series } \\
2008-2014\end{array}$ & $\begin{array}{l}\text { Median age } 74 \text { yrs } \\
\text { Median Gleason } 7 \\
\text { Primary Tx was surgery, EBRT, or BT } \\
\text { Median PSA } 4.2 \mathrm{ng} / \mathrm{mL} \\
\text { Median FU } 2.0 \mathrm{yrs} \\
\end{array}$ & $\begin{array}{l}\text { SBRT for } \\
\text { oligometastasis }\end{array}$ & $\begin{array}{l}\text { bFFS: } 44 \% \text { at } 2 \text { yrs } \\
\text { OS: } 95 \% \text { at last FU } \\
1 \text { patient with failure within the treatment field }\end{array}$ & $\begin{array}{l}\text { Grade } 2 \text { toxicity in one case (acute phase } \\
\text { diarrhea) } \\
\text { Grade } 3 \text { toxicity in one case (late phase } \\
\text { dyspepsia) }\end{array}$ \\
\hline $\begin{array}{l}\text { Porres et al. }{ }^{48} \\
2017 \\
\mathrm{~N}=87\end{array}$ & $\begin{array}{l}\text { German prospective } \\
\text { study } \\
2009-2016\end{array}$ & $\begin{array}{l}\text { Mean age } 66.7 \text { yrs } \\
\text { Mean pre-salvage PSA } 2.63 \mathrm{ng} / \mathrm{mL} \\
\text { Primary Tx was RP in } 87.4 \%+/- \\
\text { adjuvant or salvage RT. Primary tx of } \\
\text { RT in } 10.3 \% \text { of patients. } \\
\text { Median FU } 1.8 \text { yrs }\end{array}$ & $\begin{array}{l}\text { Salvage pelvic } \\
\text { lymph node } \\
\text { dissection (sLND) }\end{array}$ & $\begin{array}{l}\text { Only } 69 \text { patients with complete follow up included in } \\
\text { survival analysis } \\
\text { bFFS: } 35.5 \% \text { and } 27.3 \% \text { at } 1 \text { and } 5 \text { yrs } \\
\text { Systemic therapy-free survival: } 63.4 \% \text { and } 35.1 \% \text { at } 1 \text { and } \\
5 \text { yrs. } \\
\text { Number of positive lymph nodes and biochemical } \\
\text { response } 6 \text { weeks after surgery were identified as } \\
\text { predictors of bFFS and ADT-free survival. }\end{array}$ & $\begin{array}{l}\text { One intraoperative obturator nerve lesion } \\
\text { Postoperative lymphocele occurred in } 11.5 \% \text { of } \\
\text { cases, half of which required surgical } \\
\text { intervention. Two patients with obstructive } \\
\text { ileus also required surgery. }\end{array}$ \\
\hline $\begin{array}{l}\text { Karnes et al. }{ }^{49} \\
2015 \\
\mathrm{~N}=52\end{array}$ & $\begin{array}{l}\text { Mayo Clinic } \\
\text { retrospective case } \\
\text { series 2009-2013 }\end{array}$ & $\begin{array}{l}\text { Median age } 60 \text { yrs } \\
\text { Median pre-salvage PSA } 2.2 \mathrm{ng} / \mathrm{mL} \\
\text { Primary Tx was RP in all cases } \\
\text { Other therapy after RP in } 78.8 \% \text { of } \\
\text { cases before sLND } \\
\text { Median FU } 1.7 \mathrm{yrs}\end{array}$ & $\begin{array}{l}\text { Salvage pelvic } \\
\text { lymph node } \\
\text { dissection (sLND) } \\
82.7 \% \text { received } \\
\text { adjuvant hormone } \\
\text { therapy }\end{array}$ & $\begin{array}{l}\text { bFFS: } 45.5 \% \text { at } 3 \text { yrs } \\
\text { MFS: } 46.9 \% \text { at } 3 \text { yrs } \\
\text { CSS: } 92.5 \% \text { at } 3 \text { yrs } \\
\text { No further treatment after sLND in } 46.2 \% \text { of patients at } \\
\text { last follow up. }\end{array}$ & \\
\hline \multicolumn{6}{|c|}{ Androgen Deprivation Therapy (ADT) } \\
\hline $\begin{array}{l}\text { Duchesne et } \\
\text { al. }^{53} \\
2016 \\
\mathrm{~N}=261\end{array}$ & $\begin{array}{l}\text { Randomized Phase } 3 \\
\text { trial } \\
2004-2012\end{array}$ & $\begin{array}{l}\text { Group 1: patients with PSA relapse } \\
\text { after tx. No more than } 12 \mathrm{~m} \text { adj or } \\
\text { neoadj ADT and ADT must have been } \\
\text { completed at least } 12 \mathrm{~m} \text { prior to } \\
\text { randomization. }\end{array}$ & $\begin{array}{l}\text { Immediate vs } \\
\text { delayed ADT } \\
\text { Immediate: } \\
\text { received tx within } 8\end{array}$ & $\begin{array}{l}\text { Combined: } 5 \text { year OS } 86.4 \% \text { in delayed vs } 91.2 \% \text { in } \\
\text { immediate. Trend toward increased survival in immediate } \\
\text { with unadjusted HR of } 0.55(95 \% \text { CI } 0.30-1.00 ; \mathrm{p}=0.050) \\
\text { Group } 1 \text { results: }\end{array}$ & $\begin{array}{l}\text { Delayed arm demonstrated fewer treatment } \\
\text { associated adverse events than immediate arm. } \\
\text { Did not demonstrate relevant difference in } \\
\text { quality of life between arms }\end{array}$ \\
\hline
\end{tabular}




\begin{tabular}{|c|c|c|c|c|c|}
\hline & & $\begin{array}{l}\text { Group 2: Asymptomatic men unsuitable } \\
\text { for curative tx because of age, } \\
\text { comorbidity, or locally advanced } \\
\text { disease. } \\
\text { Excluded if PSA- doubling time }<, 3 \\
\text { months } \\
\text { Median FU } 5.0 \text { yrs }\end{array}$ & $\begin{array}{l}\text { weeks of } \\
\text { randomization } \\
\text { Delayed: Treatment } \\
\text { was not to begin } \\
\text { until at least } 2 \text { years } \\
\text { after randomization } \\
\text { unless symptoms or } \\
\text { mets developed, or } \\
\text { PSA doubling time } \\
\text { decreased to }<6 \mathrm{~m} .\end{array}$ & $\begin{array}{l}5 \text { year OS } 78.2 \% \text { vs } 84.3 \% \text { for delayed vs immediate tx } \\
\text { respectively. The adjusted HR for death was } 0.54 \text { in favor } \\
\text { of immediate tx but not statistically significant }(p=0.074) \text {. } \\
\text { Statistically significant difference in local progression that } \\
\text { favored immediate tx but this was not observed with } \\
\text { distant progression. } \\
41 \% \text { of men in delayed arm did not reach a trigger (in } \\
\text { other words they made it the full } 2 \text { years before starting } \\
\text { ADT) }\end{array}$ & \\
\hline $\begin{array}{l}\text { Crook et al. }{ }^{54} \\
2012 \\
\mathrm{~N}=1,386\end{array}$ & $\begin{array}{l}\text { Randomized } \\
\text { controlled trial } \\
1999-2005\end{array}$ & $\begin{array}{l}\text { Definitive RT }>12 \mathrm{~m} \text { before enrollment } \\
\text { PSA }>3 \mathrm{ng} / \mathrm{mL} \text { and higher than post-RT } \\
\text { nadir } \\
\text { No evidence of mets } \\
\text { Serum testosterone }>5 \mathrm{nmol} / \mathrm{L} \\
\text { Life expectance }>5 \mathrm{y} \\
\text { Median FU } 6.9 \mathrm{yrs}\end{array}$ & $\begin{array}{l}\text { Intermittent } \\
\text { androgen } \\
\text { deprivation (IAD) } \\
\text { vs continuous } \\
\text { androgen } \\
\text { deprivation (CAD) } \\
\text { IAD: } 8 \text { months of } \\
\text { treatment followed } \\
\text { by surveillance } \\
\text { until PSA above } 10 \\
\text { ng/mL }\end{array}$ & $\begin{array}{l}\text { Median overall survival was } 8.8 \text { years in intermittent- } \\
\text { therapy group and } 9.1 \text { years in the continuous-therapy } \\
\text { group. } \\
\text { HR for death with IAD vs CAD was } 1.02(95 \% \mathrm{CI}, 0.86 \text { to } \\
1.21 \text { ) which met noninferiority criteria }(\mathrm{HR}<1.25) \text { with a } \\
\text { p-value of } 0.009 \\
\text { Significant improved outcomes across groups: age }<75 \mathrm{yr} \text {, } \\
>3 \text { yr since RT, baseline PSA } 3-15 \mathrm{ng} / \mathrm{mL} \text {, and no prior } \\
\text { HT. }\end{array}$ & $\begin{array}{l}\text { QOL: } \\
\text {-Functional domains non-significant trend in } \\
\text { favor of IAD } \\
\text {-Symptoms: Hot flashes, desire for sexual } \\
\text { activity, and urinary symptoms all significantly } \\
\text { better with IAD ( } \mathrm{p}<0.05 \text { ) in addition to a trend } \\
\text { toward improved fatigue }(\mathrm{p}=0.07) \text {. } \\
\text { Potency on IAD: only } 29 \% \text { of those potent at } \\
\text { baseline recovered potency during non- } \\
\text { treatment interval. }\end{array}$ \\
\hline $\begin{array}{l}\text { Hussain et al. }{ }^{55} \\
2013 \\
\mathrm{~N}=1,535\end{array}$ & $\begin{array}{l}\text { Randomized } \\
\text { controlled trial } \\
1995-2008\end{array}$ & $\begin{array}{l}\text { Prior radiation therapy in } 29 \% \text { and prior } \\
\text { radical prostatectomy in about } 20 \% \text { of } \\
\text { patients. } \\
\text { All patients had metastatic disease } \\
\text { Median age } 70 \text { yrs } \\
\text { Median pre-ADT PSA: } 42 \mathrm{ng} / \mathrm{mL} \\
\text { Patients were randomized after showing } \\
\text { response to ADT }\end{array}$ & $\begin{array}{l}\text { Intermittent } \\
\text { androgen } \\
\text { deprivation (IAD) } \\
\text { vs continuous } \\
\text { androgen } \\
\text { deprivation (CAD) } \\
\text { Patients received } \\
\text { luteinizing } \\
\text { hormone-releasing } \\
\text { hormone agonist } \\
\text { and anti-androgen } \\
\text { agent. }\end{array}$ & $\begin{array}{l}\text { They could not demonstrate statistically significant } \\
\text { inferiority or non-inferiority of IAD compared to CAD. } \\
\text { The IAD group experienced more deaths with HR } 1.10 \text { but } \\
90 \% \text { CI ( } 0.99,1.23) \text {. Median survival after enrollment was } \\
5.7 \text { yrs for IAD vs } 6.4 \text { yrs for CAD }\end{array}$ & $\begin{array}{l}\text { IAD was associated with better quality of life } \\
\text { related to impotence }(\mathrm{p}<0.001) \text {, libido }(\mathrm{p}=0.04) \text {, } \\
\text { and mental health }(\mathrm{p}=0.003) \\
\text { At } 15 \text { months, } 78 \% \text { of the IAD group had } \\
\text { resumed hormone therapy. }\end{array}$ \\
\hline \multicolumn{6}{|c|}{ Chemotherapy } \\
\hline $\begin{array}{l}\text { James et al. }{ }^{56} \\
2016 \\
\mathrm{~N}=2962\end{array}$ & $\begin{array}{l}\text { RCT } \\
2005-2013\end{array}$ & $\begin{array}{l}\text { Median age } 65 \text { yrs } \\
\text { Prior local therapy in } 6 \% \text { of patients. } \\
\text { M+ disease in } 61 \%, \mathrm{~N}+/ \mathrm{X} \text { M0 in } 15 \% \text {, } \\
\text { N0M0 in } 24 \% \text {. } \\
\text { Median FU } 3.6 \text { yrs }\end{array}$ & $\begin{array}{l}\text { Four groups: } \\
\text { Standard of care } \\
\text { (SOC) only (HT), } \\
\text { SOC +zoledronic } \\
\text { acid (ZA), SOC + } \\
\text { docetaxel (Doc), } \\
\text { and SOC + ZA } \\
\text { +Doc }\end{array}$ & $\begin{array}{l}\text { Survival advantage identified for SOC }+ \text { Doc }(\mathrm{HR} 0.78 \text {, } \\
95 \% \text { CI } 0.66-0.93 ; \mathrm{p}=0.006 \text { ) and SOC }+\mathrm{ZA}+\mathrm{Doc}(\mathrm{HR} \\
0.82,95 \% \text { CI } 0.69-0.97 ; \mathrm{p}=0.022) \text { groups versus the SOC } \\
\text { alone group } \\
\text { Failure free survival advantage for SOC + Doc }(\mathrm{HR} 0.61 \text {, } \\
\left.95 \% \text { CI } 0.53-0.70 ; \mathrm{p}=0.413 \times 10^{-13}\right) \text { and SOC }+\mathrm{ZA}+\text { Doc } \\
\left(\mathrm{HR} 0.62,95 \% \mathrm{CI} 0.54-0.70 ; 0.134 \times 10^{-12}\right)\end{array}$ & $\begin{array}{l}\text { Grade } 3-5 \text { toxicity occurred in } 52 \% \text { of patients } \\
\text { in both the SOC + Doc and SOC + ZA + Doc } \\
\text { groups overall. } \\
\text { At } 6 \text { months after treatment, Grade } 3-5 \text { toxicity } \\
\text { occurred in } 17 \% \text { for SOC only, } 15 \% \text { for SOC + } \\
\text { ZA, } 36 \% \text { for SOC + Doc, and } 39 \% \text { for SOC + } \\
\text { ZA + Doc }\end{array}$ \\
\hline $\begin{array}{l}\text { James et al. }{ }^{57} \\
2017 \\
\mathrm{~N}=1917\end{array}$ & $\begin{array}{l}\text { RCT } \\
2011-2014\end{array}$ & $\begin{array}{l}\text { Median age } 67 \mathrm{yrs} \\
\text { Median PSA } 53 \mathrm{ng} / \mathrm{mL} \\
\text { Median FU } 3.3 \mathrm{yrs} \\
\text { Additional RT in } 41 \% \\
\text { Included patients who were newly } \\
\text { diagnosed and metastatic, high risk } \\
\text { locally advanced, or relapsed after } \\
\text { primary surgery or RT. }\end{array}$ & $\begin{array}{l}\text { ADT alone vs } \\
\text { combination } \\
\text { therapy (ADT plus } \\
\text { abiraterone acetate } \\
\text { and prednisolone) }\end{array}$ & $\begin{array}{l}\text { Failure free survival: } 75 \% \text { in combination therapy group } \\
\text { vs } 45 \% \text { in } \mathrm{ADT} \text { alone group (HR } 0.29 ; 95 \% \mathrm{CI}, 0.25 \text { to } \\
0.34 ; \mathrm{p}<0.001 \text { ) at } 3 \text { yrs } \\
\mathrm{CSS}: 76 \% \text { in combination group vs } 82 \% \text { in } \mathrm{ADT} \text { alone } \\
\text { group overall }\end{array}$ & $\begin{array}{l}\text { Any grade } 3 \text { or higher adverse event in } 47 \% \text { of } \\
\text { combination group vs } 33 \% \text { of ADT alone } \\
\text { group. } \\
\text { Grade } 5: 12 \text { events in combination group vs } 3 \\
\text { events in the ADT along group. }\end{array}$ \\
\hline $\begin{array}{l}\text { Sweeney et al. }{ }^{58} \\
2015\end{array}$ & $\begin{array}{l}\text { RCT } \\
2006-2012\end{array}$ & $\begin{array}{l}\text { Median age } 64 \text { yrs in ADT + Doc group } \\
\text { and } 63 \text { yrs in ADT alone group }\end{array}$ & $\begin{array}{l}\text { ADT alone vs ADT } \\
+ \text { Docetaxel (Doc) }\end{array}$ & $\begin{array}{l}\text { Overall survival benefit for ADT + Doc group over ADT } \\
\text { alone (HR } 0.61 ; 95 \% \mathrm{CI} 0.47-0.80 ; \mathrm{p}<0.001)\end{array}$ & $\begin{array}{l}\text { Grade } 3 \text { toxicity occurred in } 16.7 \% \text { of patients. } \\
\text { Grade } 4 \text { toxicity occurred in } 12.6 \% \text { of patients. }\end{array}$ \\
\hline
\end{tabular}




\begin{tabular}{|c|c|c|c|c|c|}
\hline $\mathrm{N}=790$ & & $\begin{array}{l}\text { Median PSA at start of ADT was } 50.9 \\
\text { in ADT + Doc group and } 52.1 \text { in ADT } \\
\text { alone group } \\
\text { No local therapy in } 72.8 \% \text { in both } \\
\text { groups. Primary tx of RT or RP in } \\
\text { others } \\
\text { Median FU } 2.4 \text { yrs }\end{array}$ & & $\begin{array}{l}\text { Decrease in PSA level to }<0.2 \mathrm{ng} / \mathrm{mL} \text { occurred in } 27.7 \% \\
\text { in the ADT + Doc group and } 16.8 \% \text { in ADT alone group } \\
(\mathrm{p}<0.001) \text {. } \\
\text { Median time to castration resistant disease was } 20.2 \\
\text { months for ADT + Doc group vs } 11.7 \text { months for ADT } \\
\text { alone (HR } 0.61 ; 95 \% \text { CI } 0.51-0.72 ; \mathrm{p}<0.001)\end{array}$ & $\begin{array}{l}\text { One patient experienced grade } 5 \text { toxicity event } \\
\text { (sudden death). } \\
\text { Most common grade } 3-4 \text { events were fatigue, } \\
\text { neutropenia, and febrile neutropenia. }\end{array}$ \\
\hline $\begin{array}{l}\text { McKay et al. }{ }^{59} \\
2015 \\
\mathrm{~N}=41\end{array}$ & $\begin{array}{l}\text { Single arm phase } 2 \\
\text { study } \\
2008-2010\end{array}$ & $\begin{array}{l}\text { Median age } 58-60 \text { yrs } \\
\text { Previous tx included RP in } 36,29 \text { of } \\
\text { whom received salvage RT. The other } 5 \\
\text { patients had primary RT. } \\
\text { Median FU } 2.3 \text { yrs }\end{array}$ & $\begin{array}{l}\text { Docetaxel, } \\
\text { bevacizumab, } \\
\text { dexamethasone, } \\
\text { and ADT }\end{array}$ & $\begin{array}{l}80 \% \text { developed PSA progression with median time to } \\
\text { progression of } 27.5 \text { months }\end{array}$ & $\begin{array}{l}\text { Grade } 3 \text { treatment related adverse events in } \\
39 \% \\
\text { Grade } 4 \text { treatment related adverse events in } \\
12 \%\end{array}$ \\
\hline
\end{tabular}

Acronym definitions:

Salvage radical prostatectomy (SRP); external beam radiation therapy (EBRT); low dose rate brachytherapy (LDR BT); high dose rate brachytherapy (HDR BT); salvage cryotherapy (SC); high intensity focused ultrasound (HIFU); stereotactic body radiation therapy (SBRT); biochemical recurrence (BCR); biochemical failure-free survival (bFFS); cancer specific survival (CSS); progression free survival (PFS); disease free survival (DFS); metastasis free survival (MFS); distant metastasis free survival (DMFS); overall survival (OS); prostate specific antigen (PSA); androgen deprivation therapy (ADT); hormone therapy (HT); castration resistant prostate cancer (CRPC); lymph nodes (LN); follow up (FU); quality of life (QOL) 
Citations

1. Torre LA, Bray F, Siegel RL, Ferlay J. Global Cancer Statistics , 2012. 2015;65(2):87-108. doi:10.3322/caac.21262.

2. Burt LM, Shrieve DC, Tward JD. Factors influencing prostate cancer patterns of care: An analysis of treatment variation using the SEER database. Adv Radiat Oncol. 2018;3(2):170-180. doi:10.1016/j.adro.2017.12.008.

3. Oglio PD, Valiquette AS, Tian Z, Trudeau V, Larcher A. Treatment trends and Medicare reimbursements for localized prostate cancer in elderly patients. Can Urol Assoc J. 2018;12(7):E338-E344. doi:doi: 10.5489/cuaj.4865.

4. Nguyen PL, D'Amico A V., Lee AK, Suh WW. Patient selection, cancer control, and complications after salvage local therapy for postradiation prostate-specific antigen failure: A systematic review of the literature. Cancer. 2007;110(7):1417-1428. doi:10.1002/cncr.22941.

5. Zagars GK, Pollack A. Kinetics of serum prostate-specific antigen after external beam radiation for clinically localized prostate cancer. Radiother Oncol. 1997;44:213-221.

6. Tran H, Kwok J, Pickles T, Tyldesley S, Black PC. Underutilization of local salvage therapy after radiation therapy for prostate cancer. Urol Oncol Semin Orig Investig. 2014;32(5):701-706. doi:10.1016/j.urolonc.2013.12.014.

7. Roach M, Hanks G, Thames H, et al. Defining biochemical failure following radiotherapy with or without hormonal therapy in men with clinically localized prostate cancer: Recommendations of the RTOG-ASTRO Phoenix Consensus Conference. Int J Radiat Oncol Biol Phys. 2006;65(4):965-974. doi:10.1016/j.ijrobp.2006.04.029.

8. Slovin SF, Wilton AS, Heller G, Scher HI. Time to Detectable Metastatic Disease in Patients with Rising Prostate-Specific Antigen Values following Surgery or Radiation Therapy. Clin Cancer Res. 2005;11(24):2576-2579. doi:10.1158/1078-0432.ccr-05-1668.

9. Freedland SJ, Moul JW. Prostate Specific Antigen Recurrence After Definitive Therapy. J Urol. 2007;177(6):1985-1991. doi:10.1016/j.juro.2007.01.137.

10. Stephenson AJ, Shariat SF, Zelefsky MJ, et al. Salvage Radiotherapy for Recurrent Prostate Cancer After Radical Prostatectomy. JAMA. 2004;291(11):1325-1332. doi:10.1001/jama.291.11.1325.

11. Zumsteg ZS, Spratt DE, Romesser PB, et al. Anatomic Patterns of Recurrence Following Biochemical Relapse in the Dose-Escalation Era for Prostate Patients Undergoing External Beam Radiotherapy. J Urol. 2015;194(6):1624-1630. doi:10.1016/j.juro.2015.06.100.

12. Sartor O, de Bono JS. Metastatic Prostate Cancer. N Engl J Med. 2018;378(7):645-657. doi:10.1056/NEJMra1701695.

13. Glaser ZA, Rais-Bahrami S. Fluciclovine positron emission tomography in the setting of biochemical recurrence following local therapy of prostate cancer. Transl Androl Urol. 2018;7(5):824-830. doi:10.21037/tau.2018.07.17.

14. Zacho HD, Nielsen JB, Dettmann K, et al. 68Ga-PSMA PET/CT in Patients With Biochemical Recurrence of Prostate Cancer. Clin Nucl Med. 2018;43(8):579-585. doi:10.1097/RLU.0000000000002169.

15. Afshar-Oromieh A, Holland-Letz T, Giesel FL, et al. Diagnostic performance of 68Ga-PSMA-11 
(HBED-CC) PET/CT in patients with recurrent prostate cancer: evaluation in 1007 patients. Eur $J$ Nucl Med Mol Imaging. 2017;44(8):1258-1268. doi:10.1007/s00259-017-3711-7.

16. Zelefsky MJ, Ben-Porat L, Scher HI, et al. Outcome predictors for the increasing PSA state after definitive external-beam radiotherapy for prostate cancer. J Clin Oncol. 2005;23(4):826-831. doi:10.1200/JCO.2005.02.111.

17. NCCN. Prostate Cancer NCCN Evidence Blocks. 2018.

18. Chade DC, Shariat SF, Cronin AM, et al. Salvage radical prostatectomy for radiation-recurrent prostate cancer: A multi-institutional collaboration. Eur Urol. 2011;60(2):205-210. doi:10.1016/j.eururo.2011.03.011.

19. Mandel P, Steuber T, Ahyai S, et al. Salvage radical prostatectomy for recurrent prostate cancer: Verification of European Association of Urology guideline criteria. BJU Int. 2016;117(1):55-61. doi:10.1111/bju.13103.

20. Sanderson KM, Penson DF, Cai J, et al. Salvage Radical Prostatectomy: Quality of Life Outcomes and Long-Term Oncological Control of Radiorecurrent Prostate Cancer. J Urol. 2006;176(5):2025-2032. doi:10.1016/j.juro.2006.07.075.

21. Ward JF, Sebo TJ, Blute ML, Zincke H. Salvage surgery for radiorecurrent prostate cancer: Contemporary outcomes. J Urol. 2005;173(4):1156-1160. doi:10.1097/01.ju.0000155534.54711.60.

22. Vargas C, Swartz D, Vashi A, et al. Salvage brachytherapy for recurrent prostate cancer. Brachytherapy. 2014;13(1):53-58. doi:10.1016/j.brachy.2013.10.012.

23. Baumann BC, Baumann JC, Christodouleas JP, Soffen E. Salvage of locally recurrent prostate cancer after external beam radiation using reduced-dose brachytherapy with neoadjuvant plus adjuvant androgen deprivation. Brachytherapy. 2017;16(2):291-298.

doi:10.1016/j.brachy.2016.12.011.

24. Grado GL, Collins JM, Kriegshauser JS, et al. Salvage Brachytherapy for Localized Prostate Cancer After Radiotherapy Failure. Urology. 1999;53(1).

25. Burri RJ, Stone NN, Unger P, Stock RG. Long-term outcome and toxicity of salvage brachytherapy for local failure after initial radiotherapy for prostate cancer. Int J Radiat Oncol Biol Phys. 2010;77(5):1338-1344. doi:10.1016/j.ijrobp.2009.06.061.

26. Crook JM, Zhang P, Pisansky TM, et al. A Prospective Phase 2 Trial of Transperineal UltrasoundGuided Brachytherapy for Locally Recurrent Prostate Cancer After External Beam Radiation Therapy (NRG Oncology/RTOG-0526). Int J Radiat Oncol Biol Phys. 2019;103(2):335-343. doi:10.1016/j.ijrobp.2018.09.039.

27. Moman MR, Poel HG Van Der, Battermann JJ, Moerland MA, Vulpen M Van. Treatment outcome and toxicity after salvage 125-I implantation for prostate cancer recurrences after primary 125-I implantation and external beam radiotherapy. Brachytherapy. 2010;9(2):119-125. doi:10.1016/j.brachy.2009.06.007.

28. Chen CP, Weinberg V, Shinohara K, et al. Salvage HDR Brachytherapy for Recurrent Prostate Cancer After Previous Definitive Radiation Therapy : 5-Year Outcomes. Int J Radiat Oncol Biol Phys. 2013;86(2):324-329. doi:10.1016/j.ijrobp.2013.01.027.

29. Yamada Y, Kollmeier MA, Pei X, et al. A Phase II study of salvage high-dose-rate brachytherapy for the treatment of locally recurrent prostate cancer after definitive external beam radiotherapy. 
Brachytherapy. 2014;13(2):111-116. doi:10.1016/j.brachy.2013.11.005.

30. Pisters LL, Von Eschenbach A, Scott SM, et al. The Efficacy and Complications of Salvage Cryotherapy of the Prostate. J Urol. 1997;157:921-925.

31. Mazur P. Cryobiology : The Freezing of Biological Systems. Science (80- ). 1970;168(3934):939949.

32. Wenske S, Quarrier S, Katz AE. Salvage Cryosurgery of the Prostate for Failure After Primary Radiotherapy or Cryosurgery : Long-term Clinical, Functional, and Oncologic Outcomes in a Large Cohort at a Tertiary Referral Centre. Eur Urol. 2013;64:1-7. doi:10.1016/j.eururo.2012.07.008.

33. Williams AK, Martinez CH, Lu C, Ng CK, Pautler SE, Chin JL. Disease-Free Survival Following Salvage Cryotherapy for Biopsy-Proven Radio-Recurrent Prostate Cancer. 2011;60:405-410. doi:10.1016/j.eururo.2010.12.012.

34. Perrotte P, Litwin MS, McGuire EJ, Scott SM, Von Eschenbach AC, Pisters LL. Quality of life after salvage cryotherapy: The impact of treatment parameters. J Urol. 1999;162(2):398-402.

35. Ng CK, Moussa M, Downey DB, Chin JL. Salvage Cryoablation of the Prostate : Followup and Analysis of Predictive Factors for Outcome. J Urol. 2007;178:1253-1257. doi:10.1016/j.juro.2007.05.137.

36. Lukka H, Waldron T, Chin J, et al. High-intensity Focused Ultrasound for Prostate Cancer: A Systematic Review. Clin Oncol. 2011;23(2):117-127. doi:10.1016/j.clon.2010.09.002.

37. Babalola O, Lee TH (Joyce), Viviano CJ. Prostate Ablation Using High Intensity Focused Ultrasound: A Literature Review of the Potential Role for Patient Preference Information. J Urol. 2018;200(3):512-519. doi:10.1016/j.juro.2018.04.066.

38. Crouzet S, Blana A, Murat FJ, et al. Salvage high-intensity focused ultrasound (HIFU) for locally recurrent prostate cancer after failed radiation therapy: Multi-institutional analysis of 418 patients. BJU Int. 2017;119(6):896-904. doi:10.1111/bju.13766.

39. Gelet A, Chapelon JY, Poissonnier L, et al. Local Recurrence of Prostate Cancer After External Beam Radiotherapy: Early Experience of Salvage Therapy Using High-Intensity Focused Ultrasonography. Urology. 2004;63(4):625-629. doi:10.1016/j.urology.2004.01.002.

40. Kanthabalan A, Peters M, Vulpen M Van, et al. Focal salvage high-intensity focused ultrasound in radiorecurrent prostate cancer. BJU Int. 2017;120:246-256. doi:10.1111/bju.13831.

41. Ahmed HU, Cathcart P, Chalasani V, et al. Whole-Gland Salvage High-Intensity Focused Ultrasound Therapy for Localized Prostate Cancer Recurrence After External Beam Radiation Therapy. Cancer. 2012;118(12):3071-3078. doi:10.1002/cncr.26631.

42. Crouzet S, Murat F, Pommier P, et al. Locally recurrent prostate cancer after initial radiation therapy: Early salvage high-intensity focused ultrasound improves oncologic outcomes. Radiother Oncol. 2012;105:198-202. doi:10.1016/j.radonc.2012.09.014.

43. Fuller DB, Naitoh J, Lee C, Hardy S, Jin H. Virtual HDR Cyberknife Treatment for Localized Prostatic Carcinoma: Dosimetry Comparison with HDR Brachytherapy and Preliminary Clinical Observations. Int J Radiat Oncol Biol Phys. 2008;70(5):1588-1597. doi:10.1016/j.ijrobp.2007.11.067.

44. Fuller DB, Wurzer J, Shirazi R, Bridge SS, Law J, Mardirossian G. High-dose-rate stereotactic 
body radiation therapy for postradiation therapy locally recurrent prostatic carcinoma : Preliminary prostate-specific antigen response, disease-free survival, and toxicity assessment. Pract Radiat Oncol. 2015;5(6):e615-e623. doi:10.1016/j.prro.2015.04.009.

45. Leroy T, Lacornerie T, Bogart E, Nickers P, Lartigau E, Pasquier D. Salvage robotic SBRT for local prostate cancer recurrence after radiotherapy : preliminary results of the Oscar Lambret Center. Radiat Oncol. 2017;12(95):1-7. doi:10.1186/s13014-017-0833-9.

46. Ost P, Reynders D, Decaestecker K, et al. Surveillance or Metastasis-Directed Therapy for Oligometastatic Prostate Cancer Recurrence: A Prospective, Randomized, Multicenter Phase II Trial. J Clin Oncol. 2017;36(5):446-454. doi:10.1200/JCO.2017.75.4853.

47. Ingrosso G, Trippa F, Maranzano E, et al. Stereotactic body radiotherapy in oligometastatic prostate cancer patients with isolated lymph nodes involvement: a two-institution experience. World J Urol. 2017;35(1):45-49. doi:10.1007/s00345-016-1860-0.

48. Porres D, Pfister D, Thissen A, et al. The role of salvage extended lymph node dissection in patients with rising PSA and PET/CT scan detected nodal recurrence of prostate cancer. Prostate Cancer Prostatic Dis. 2017;20(1):85-92. doi:10.1038/pcan.2016.54.

49. Karnes RJ, Murphy CR, Bergstralh EJ, et al. Salvage Lymph Node Dissection for Prostate Cancer Nodal Recurrence Detected by 11C-Choline Positron Emission Tomography/Computerized Tomography. J Urol. 2015;193(1):111-116. doi:10.1016/j.juro.2014.08.082.

50. Bolla M, Gonzalez D, Warde P, et al. Improved survival in patients with locally advanced prostate cancer treated with radiotherapy and goserelin. N Engl J Med. 1997;337(5):295-300. doi:10.1056/NEJM199707313370502.

51. Lu-Yao GL, Albertsen PC, Moore DF, et al. Survival Following Primary Androgen Deprivation Therapy Among Men With Localized Prostate Cancer. JAMA. 2008;300(2):173-181. doi:10.1001/jama.300.2.173.

52. Keating NL, Malley AJO, Smith MR. Diabetes and Cardiovascular Disease During Androgen Deprivation Therapy for Prostate Cancer. J Clin Oncol. 2006;24(27):4448-4456. doi:10.1200/JCO.2006.06.2497.

53. Duchesne GM, Woo HH, Bassett JK, et al. Timing of androgen-deprivation therapy in patients with prostate cancer with a rising PSA (TROG 03.06 and VCOG PR 01-03 [TOAD]): a randomised, multicentre, non-blinded, phase 3 trial. Lancet Oncol. 2016;17(6):727-737. doi:10.1016/S1470-2045(16)00107-8.

54. Crook JM, Crostopher J. O'callaghan, Duncan G, et al. Intermittent Androgen Suppresion for Rising PSA Level after Radiotherapy. N Engl J Med. 2012;367(10):895-903. doi:10.1056/NEJMoa1201546.

55. Hussain M, Tangen CM, Berry DL, et al. Intermittent versus Continuous Androgen Deprivation in Prostate Cancer. N Engl J Med. 2013;368(14):1314-1325. doi:10.1056/NEJMoa1212299.

56. James ND, Sydes MR, Clarke NW, et al. Addition of docetaxel, zoledronic acid, or both to firstline long-term hormone therapy in prostate cancer (STAMPEDE): Survival results from an adaptive, multiarm, multistage, platform randomised controlled trial. Lancet. 2016;387:1163-1177. doi:10.1016/S0140-6736(15)01037-5.

57. James ND, de Bono JS, Spears MR, et al. Abiraterone for Prostate Cancer Not Previously Treated with Hormone Therapy. N Engl J Med. 2017;377(4):338-351. doi:10.1056/NEJMoa1702900. 
58. Sweeney CJ, Chen Y-H, Carducci M, et al. Chemohormonal Therapy in Metastatic HormoneSensitive Prostate Cancer. N Engl J Med. 2015;373(8):737-746. doi:10.1056/NEJMoa1503747.

59. McKay RR, Gray KP, Hayes JH, et al. Docetaxel, bevacizumab, and androgen deprivation therapy for biochemical disease recurrence after definitive local therapy for prostate cancer. Cancer. 2015;121(15):2603-2611. doi:10.1002/cncr.29398.

60. Pound CR, Partin AW, Eisenberger MA, Chan DW, Pearson JD, Walsh PC. Natural history of progression after PSA elevation following radical prostatectomy. Jama. 1999;281(17):1591-1597. doi:10.1001/jama.281.17.1591. 